\title{
Æsa SigurJónsdótTiR
}

\section{Sjónarspil tegundanna}

\section{Hvalurinn í öllum sínum (líf) myndum}

\section{Hvalreki}

Hundruð hvalreka eru skráð við Ísland frá upphafi byggðar, en hvalreki sumarsins 2019 var að mörgu leyti einstakur. Pann 18. júlí komu erlendir ferðamenn í útsýnisflugi auga á fimmtíu dauða hvali í Löngufjörum á Snæfellsnesi. Svipaður fjöldi dýra strandaði í Garði á Reykjanesi í byrjun ágúst. Pá drápust 62 hvalir eða voru aflífaðir á Langanesi í byrjun september. Mikill fjöldi grindhvala, eða alls 136 dýr, drápust eða voru aflífuð um sumarið og haustið við strendur Íslands, en alls voru 153 hvalir skráðir af hinum ýmsu tegundum. ${ }^{1}$ Eru pá ótaldir stöku hvalir sem hugsanlega gætu hafa farið fram hjá vökulum augum landeigenda, ferða- og vísindamanna.

Petta marga hvali hafði ekki rekið á Íslandsstrendur síðan í október 1986, en pá rak 147 grindhvali í fjöruna austan við Porlákshöfn. Fólk streymdi niður í fjöru til að skoða hvalina og „sumir fengu sér í soðið“.2 Hvalirnir voru ljósmyndaðir og skráðir, auk pess sem nokkrar beinagrindur voru teknar til varðveislu fyrir Náttúrugripasafn Íslands. ${ }^{3}$ „Einnig var nokkuð um pað að fólk færi og skæri sér bita til pess að gæða sér á. “4 Hvalkjötið var

1 Ágúst Ingi Jónsson, „Mikill fjöldi grindhvala en fá svínhveli“, Morgunblaðið, 23. október 2019, bls. 4.

2 ABS, „Hvalreki í Porlákshöfn - fóðurstöðvar njóta góðs af“, Tíminn, 28. október 1986, bls. 3. Einnig: „RÚV2-44-A150“, Ríkisútvarpið, október 1986. Myndin, sem er 35 mm litskyggna, sýnir prjá karlmenn, líklega fréttamenn, ljósmynda og kvikmynda dýrin. Vefslóð myndar sótt 15.september 2019 af https://sarpur.is/Adfang. aspx?AdfangID=712716.

3 Upplýsingar frá Ævari Petersen dýrafræðingi.

4 ABS, „Hvalreki í Porlákshöfn - fóðurstöðvar njóta góðs af“, bls. 3.

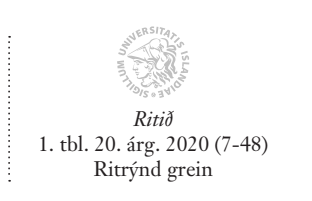

(C) 2020 Ritið, tímarit Hugvísindastofnunar og höfundur greinarinnar

Útgefandi:

Hugvísindastofnun Háskóla Íslands, Sæmundargötu 2, 102 Reykjavík
Birtist á vefnum http://www.ritid.hi.is. Tengiliður: ritið@hi.is

DOI: 10.33112 /ritid.20.1.2

Birt samkvæmt skilmálum Creative Commons BY (4.0). 
nýtt í fóðurstöðvum víðs vegar um land pví reynt var að nýta skepnurnar til hins ítrasta.

Auk peirra dýra sem rak á land síðastliðið sumar, flæktist fjöldi hvala inn í hafnir og nálægt landi og reynt var að reka pá lifandi á haf út. Petta er öfugt við pau viðbrögð sem tíðkuðust fyrir nokkrum áratugum. Pegar hvalir sáust nærri landi, pá drifu menn sig út í báta til að reka pá í land. Grindarhvalstorfa var rekin inn í Friðarhöfn í Vestmannaeyjum 5. ágúst 1958 og talið er að pá hafi allt að 400 marsvínum verið slátrað. Heimildum um fjölda dýranna ber ekki saman, en myndir og frásagnir af drápunum birtust í dagblöðum. Hvalirnir voru skornir og kjötið af peim fryst, spikið saltað, en beinunum var sökkt í sæ. ${ }^{5}$

Ekki er vitað til pess að neinn hafi nýtt kjötið sumarið 2019, enda ólöglegt að nota pað til manneldis. Hins vegar var talað um pað í fjölmiðlum að hönnuðir myndu geta smíðað skartgripi úr hvaltönnum og beinum pegar kjötið væri rotnað og beinin tekin að veðrast í sandinum. ${ }^{6}$

\section{Hvalamyndasafn}

Hvalreki, hvalveiðar, hvalaskoðun, jafnvel sagan um háhyrninginn Keikó, virðist óprjótandi viðfangsefni fræðimanna, rithöfunda, fréttamanna, kvikmyndagerðarmanna og ljósmyndara, og jafnframt birtingarform alpjóðlegrar dægurmenningar. En, hvalir eru ekki órjúfanlegur hluti villtrar, óbeislaðrar náttúru eins og látið er í veðri vaka í auglýsingum hvalaskoðunarfyrirtækjanna sem grundvalla rekstur sinn á sterkum ímyndaráhrifum dýranna. ${ }^{7}$ Hvalaskoðun byggir fyrst og fremst á tilfinningasambandi mannsins við umhverfið sem nærist á pjóðsögum og vísindalegum hugmyndum um hvali. ${ }^{8}$ Pessi sterku tilfinningaviðbrögð mannsins gagnvart náttúrunni

5 Án höfundar, „Hvalreki á fjörur Vestmannaeyinga,“ Pjóðviljinn, 7. ágúst 1958, forsíða; Án höfundar, „Um 400 marsvín rekin inn í Friðarhöfn í Eyjum“, Visir, 6. ágúst 1958, forsíða og bls. 5; Án höfundar, „Eyjamenn gera hlé á hvalskurðinum vegna pjóðhátíðarinnar,“ Morgunblaðið, 7. ágúst 1958, baksíða. Ljósmyndir eftir pá Friðrik Jensson og Oddgeir Kristjánsson birtust með fréttinni „Hvalavaða rekin í land í Vestmannaeyjum“, Fálkinn, 15. ágúst 1958, bls. 3 og 14.

6 „Tennurnar og beinin verða tekin pegar hræin rotna“, sjá viðtal blaðamanns Morgunblaðsins við Porgrím Leifsson landeiganda. Freyr Bjarnason, „Hvaltönn fyrir lengra komna „lovera““, Morgunblaðið, 22. júlí 2019, sótt 26. mars 2020 af https://www. mbl.is/frettir/innlent/2019/07/22/hvaltonn_fyrir_lengra_komna_lovera/.

7 Sjá auglýsingu ferðamannafyrirtækja til að mynda hér: https://wildlifeiceland.is/.

8 Britt Kramvig, Berit Kristoffersen og Anniken Førde, „Responsible Cohabitation in Arctic Waters. The Promise of a Spectacle Tourist Whale“, Green Ice. 
próuðust á áttunda áratug liðinnar aldar pegar umhverfissiðfræðileg sjónarmið og rannsóknir á sársauka og kvölum dýra kollvörpuðu afstöðu almennings til hvalveiða og til meðferðar manna á dýrum almennt. Frelsisímynd dýranna og sjónarspil peirra í höfunum, ekki síst í norðri, byggir á orðræðusambandi sem á rætur langt aftur í aldir, ${ }^{9}$ en ekki síður til vísindaskáldsagna og ímyndasköpunar Kalda stríðsins sem nærði afpreyingarheim norðursins, handan raunveruleika fólksins sem par bjó. ${ }^{10}$

Hér er ekki ætlunin að endursegja sögu hvalveiða á Íslandi, ræða orsakir hvalreka, eða hugsanleg áhrif hvalaskoðunar á hvalastofna, heldur er markmið greinarinnar að rýna í myndir af hvölum, til að varpa ljósi á pað hvernig upplýsingatæknisamfélagið hefur mótandi áhrif á myndlist og sjónmenningu samtímans og skapar auk pess nýjar forsendur til að túlka myndir samtímans (og fortíðarinnar) út frá sjónarhorni umhverfisfræða.

Birtingarform hvala í listum og sjónmenningu hafa lítið verið rannsökuð prátt fyrir að myndir komi talsvert við sögu í sagnfræðiritum sem fjalla um hvalveiðar við Ísland, enda eru pær mikilvægar heimildir sem bregða ljósi á próun atvinnuvega og iðnvæðingar í sjávarútvegi, um leið og pær sýna beinlínis nýtingu mannsins á hvalastofnum og viðbrögð manna við hvalreka. ${ }^{11}$ Myndirnar sem hér eru til umfjöllunar eru af ýmsum toga; handritalýsingar, tegundateikningar, prent- og ljósmyndir. Pær hafa verið valdar úr söfnum, af fréttamiðlum og gagnagrunnum, og verða greindar sem sjónmenningarlegt arkíf, einskonar „hvalamyndasafn“, sem endurspeglar breytt valda- og tilfinningatengsl manna og dýra.

Einkenni upplýsingamynda er að draga úr fagurfræðilegum áhrifum reynslunnar og sýna raunveruleikann á eins hlutlausan hátt og hægt er. Fyrstu myndirnar sem birtust af hvalrekanum í Löngufjörum voru dæmigerðar upplýsingasamfélagsmyndir, en hlutverk peirra er að sýna, deila og

Tourism Ecologies in the European High North, ritstj. Simone Abram og Katrín Anna Lund, London: Palgrave Macmillan, 2016, bls. 25-47, hér bls. 29.

9 Um sögulegar ímyndir norðurslóða má lesa í doktorsritgerð Sumarliða Ísleifssonar, Tver eyjar á jaðrinum. Ímyndir Ílands og Grenlands frá miðöldum til miðrar 19. aldar, Reykjavík: Háskóli Íslands, 2004.

10 Petta efni er rætt í bók Mette Bryld og Nina Lykke, Cosmodolphins: Feminist Cultural Studies of Technology, Animals and the Sacred, New York: Zed Books, 2000.

11 Trausti Einarsson, Hvalveiðar við Ísland 1600-1939, Reykjavík: Bókaútgáfa Menningarsjóðs, 1987; Smári Geirsson, Stórbvalaveiðar við Íland til 1915, Reykjavík: Sögufélag, 2015; Vicki Ellen Szabo, Monstrous Fishes and the Mead-Dark Sea, Leiden: Brill, 2008; Viðar Hreinsson, fón lerði og náttúrur náttúrunnar, Reykjavík: Lesstofan, 2016. 
dreifa upplýsingum samstundis á vef- og samfélagsmiðlum af hvalreka sem var nokkuð langt frá mannabyggðum. ${ }^{12}$ Myndirnar voru teknar teknar í útsýnisfluginu og úr drónum eftir að vélinni var lent í sandinum. Pær gefa nokkuð góða yfirsýn yfir tegund hvalanna og fjölda peirra, fremur en að pær miðli sterkri persónulegri eða sjónrænni reynslu peirra sem upplifðu fundinn. Myndir af öðrum hvalrekum sem birtust í fjölmiðlum sumarið 2019 sýndu hvalina á svipaðan hátt, yfirleitt úr nokkurri fjarlægð, stundum svömluðu peir magnlausir í paranum eða lágu hreyfingarlausir eða dauðir í fjöruborðinu. Tilbrigðalaust sjónarhorn ljósmyndaranna ber pess merki að hvalreki er ekki lengur hluti af ástríðufullri veiðimenningu, atvinnuháttum, eða menningarsögu. Prátt fyrir hlutleysi sitt afhjúpa myndirnar ákveðinn hamfaraótta. Vísindamenn geta enn ekki gefið neinar einhlítar skýringar á fyrirbærinu, enda eru orsakir hvalreka margvíslegar og loftslagsbreytingar gætu hugsanlega borið ábyrgð á aukinni tíðni rekanna á síðustu árum. ${ }^{13}$

\section{Hvalurinn á mannöld}

Samband manna og dýra er óræðara, opnara en nokkru sinni fyrr og hefur grafið undan kenningum um aðskilnað menningar og náttúru sem einkenndi listir og vísindi um aldir. Ný hugtök eins og hamfarahlýnun, loftslagsvá og mannöld hafa breytt viðhorfi almennings til umhverfisins og sjónarhorni fræðimanna til rannsóknarefna sinna. Frásagnir af „brotnu plánetunni“"14 lýsa nýju ástandi, jafnvel uppdrætti að breyttri heimsmynd sem hafa verið gefin hin ýmsu nöfn, sem erfitt er að pýða svo sem: Capitalocene, Chthulucene, og Ecocene. ${ }^{15}$ Öll endurspegla pessi heiti mismunandi viðmið fræðimanna á pví hvernig eigi að skilgreina mannöldina (e. anthropocene). ${ }^{16}$

Pessar ólíku útfærslur á frásögnum af lífi mannsins á jörðinni verða ekki

12 Nathan Jurgenson, The Social Photo. On Photography and Social Media, London \& New York: Verso, 2019, bls. 17.

13 Kristlín Dís Ingilínardóttir, „Loftslagsbreytingar gætu borið ábyrgð á hvalrekum“. Viðtal við Gísla Víkingsson, Fréttablaðið, 13. ágúst 2019. Sótt 10. september 2019 af https://www.frettabladid.is/frettir/loftslagsbreytingar-gaetu-borid-abyrgd-hvalrekum/.

14 Hér er vísað í titil bókar Önnu Tsing, Heather Anne Swanson, Elaine Gan og Nils Bubandt, Arts of Living on a Damaged Planet. Ghosts and Monsters of the Anthropocene, ritstj. Nils Bubandt, Minneapolis og London: University of Minnesota Press, 2017.

15 T. J. Demos, ræðir pessi hugtök í sjónmenningarlegu samhengi í ritinu Against the Antbropocene. Visual Culture and Environment Today, Berlin: Sternberg Press, 2017.

16 Donna Haraway, „Anthropocene, Capitalocene, Plantatioocene, Chthulucene: Makin Kin“, Environmental Humanities 6/2015, bls. 159-165. 


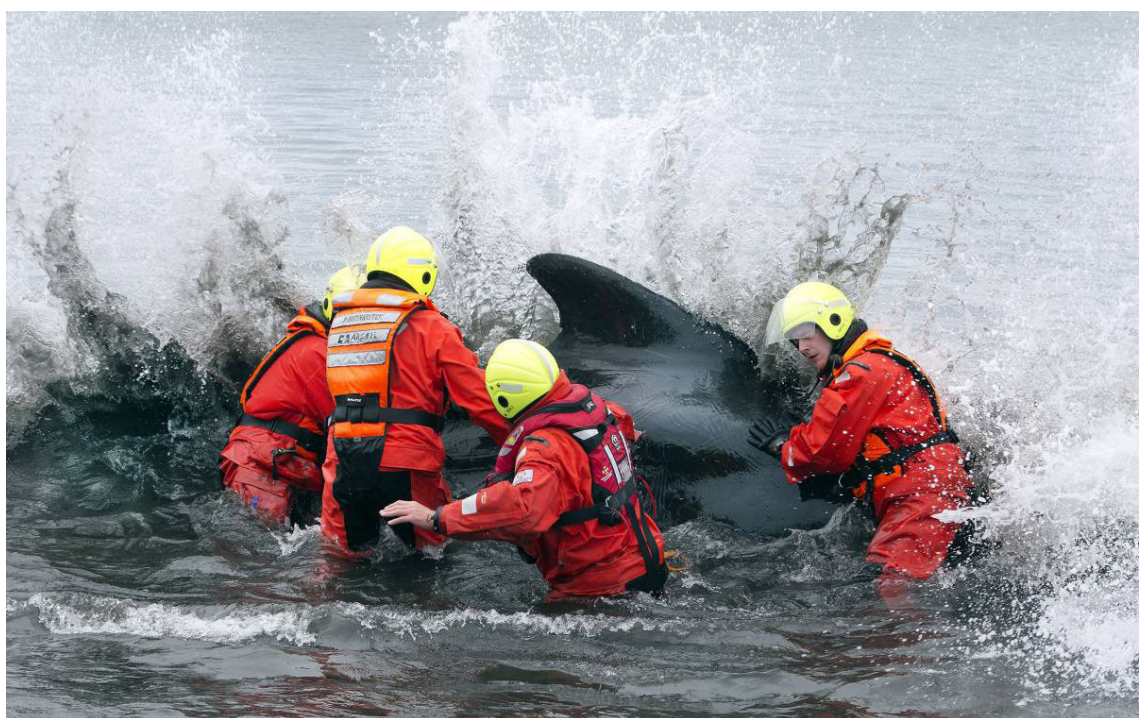

Stefán Karlsson, björgunarsveitarmenn reyna að bjarga grindhval úr Káravík við Seltjarnarnes 26. ágúst 2019. Myndin birtist á forsíðu Fréttablaðsins 27. ágúst 2019.

ræddar hér, en til að bera kennsl á og greina pessar nýju aðstæður í samtímamenningu okkar er mikilvægt að líta til baka og reyna að tengja saman ólíkar heimildir og fræðasvið. Slík flétta veltir upp spurningum um birtingu valdsins í myndum fortíðarinnar og próun samfélagsmynda upplýsingatæknisamfélagsins, um leið og bent verður á hvernig myndlistarmenn afhjúpa tengsl síð-kapítalisma og fagurfræði í verkum sínum.

Pví verður haldið fram að áhyggjur manna af lífríkinu megi merkja í frétta- og samfélagsljósmyndum. Sýnt verður fram á að myndir megi skoða í ljósi kenninga um lífvaldið, hugtak sem gerir okkur kleift að bera kennsl á framgang félagslegra hátta og umbreytingu kapítalískra framleiðsluhátta frá einveldi til ögunar- og stýringarsamfélags samtímans. ${ }^{17}$ Fyrst verður sýnt fram á að ljósmyndir af hvalreka teknar sumarið 2019 endurspegli pessi skil sem birtast m.a. í umhyggju- og umönnunarsamfélagi samtímans. ${ }^{18} \mathrm{Um}-$ hverfissiðfræði virðist hafa haft áhrif á fjölmiðla meginstraumanna og ljósmynd Stefáns Karlssonar, fréttaljósmyndara, sem birtist á forsíðu Fréttablaðsins 27. ágúst 2019 verður tekin sem dæmi um sjónarhorn sem sýnir grindhval nánast á jafningjagrundvelli við manninn.

17 Michael Hardt og Antonio Negri, „Lífpólitísk framleiðsla“, Viðar Porsteinsson pýddi, Hugur 1/2003, bls. 150-173, hér bls 156-157.

18 Hjörleifur Finnsson, „Af nýju lífvaldi. Líftækni, nýfrjálshyggja og lífsiðfræði“, Hugur 1/2003, bls. 174-196, hér bls. 178 . 
Pví er öfugt farið í handritalýsingum sem hafa varðveist frá miðöldum, nánar tiltekið í upphafsstöfum í rekapætti í premur ólíkum fónsbókarbandritum. Par er yfirburðum mannsins yfir dýrinu miðlað í einföldum valdskilaboðum sem táknuð eru með eggvopnum og sveðjum. Í náttúrulýsingum og á landakortum sextándu og sautjándu aldar sést hins vegar hvernig tilraun var gerð til að efla pekkingu á heiminum með pví að draga upp myndir af ólíkum tegundum dýra, sýna tegundareinkenni peirra, og safna saman reynslupekkingu um pau. Petta var gert með pví að lýsa útliti hvala í smáatriðum og sýna athafnir manna við hvalveiðar og hvalskurð. Um var að ræða tilraun til að draga upp einskonar heildarmynd af lífríkinu, eða tilbrigði við heimsmynd sem ætlað var að endurspegla veröldina í öllum sínum margbreytileika.

Eins og Michel Foucault benti á pá var markmið lífvaldsins að auka getu og framleiðni einstaklinga og tengdist pví uppgangi iðnvæðingar og kapítalisma í Evrópu. Landakortin eru gott dæmi um pekkingarsköpun sem hafði pað að markmiði að auka útpenslu, færni og framleiðni samfélaga. Á Carta Marina (1539), landakortinu sem talið er gert af síðasta sænska kapólska biskupnum, kortagerðarmanninum og fræðimanninum Olaus Magnus (1490-1557), sést hvernig heimsmyndin er dregin upp í óljósu merkingarrými á milli eldri pekkingar, reynslu sjómanna og óstaðfestra frásagna peirra.

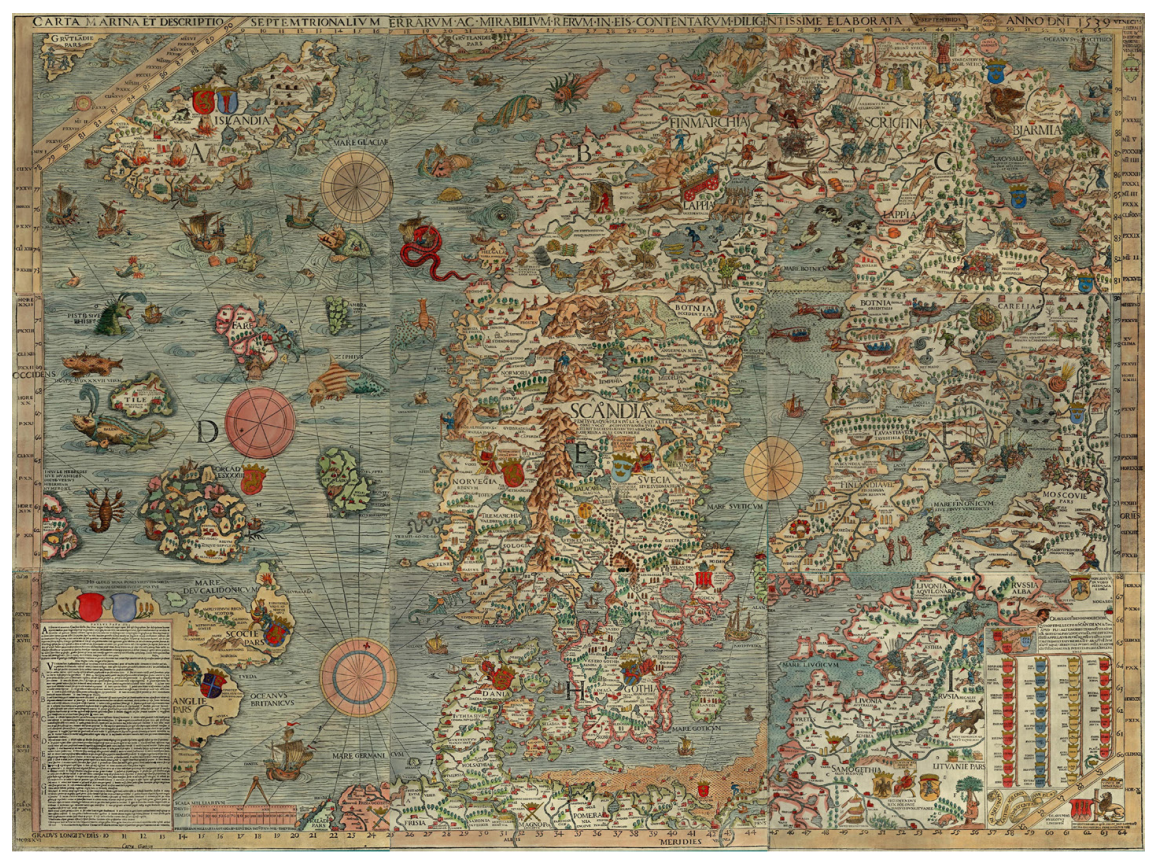

Olaus Magnus (1490-1557), Carta marina, 1539. James Ford Bell Library. 
Myndir Olaus Magnus, sem einnig birtust í ritum hans, sýna menn, skip, hvali og ýmsar ókindir í hafinu. Pær lýsa veiðum og varpa ljósi á athafnir manna í Norðurhöfum. Heimsmynd hans er einkennilegur blendingur eldri pekkingar og skáldskapar. Myndirnar endurvarpa ímyndunum um náttúruna, eins og teikning Olaus Magnus sem rímar við lýsingu í Konungs skuggsjá á hvalnum Skeljungi, illhveli sem leggst fyrir skip. ${ }^{19}$

Slíkar truflanir skáldskaparins voru hreinsaðar í burtu í erlendum náttúruritum pegar pekking manna var orðin meiri á lífríkinu og myndir fengu markvissara hlutverk sem trúverðug birtingarmynd náttúrunnar gerð eftir lifandi fyrirmynd. Teikningin varð upplýsandi miðill, einskonar hjálpartæki vísindanna sem listamenn beittu ýmist til að draga upp heildarmynd af náttúrunni eða til að lýsa henni í smáatriðum. Ný tegund upplýsingamynda varð til utan listrýmisins. ${ }^{20}$ Pær skyldu byggja á reynslunni og helst vera gerðar ad vivum, eða í návist hlutarins sem teiknaður var. ${ }^{21}$ Slíkar náttúrumyndir urðu sýnishorn, einskonar sönnunargagn sem styrktu sannleiksgildi flokkunarkerfa. Auk pess gegndu pær almennu uppfræðsluhlutverki um fyrirbæri náttúrunnar, eins og teikningarnar í Ferðabók Eggerts Ólafssonar og Bjarna Pálssonar um ferðir peirra á Íslandi árin 1752-1757.22

Tengsl hvalveiða og ljósmyndunar á Íslandi hafa nánast ekkert verið könnuð. Sigfús Eymundsson (1837-1911), fyrsti íslenski atvinnuljósmyndarinn, lærði ljósmyndun í Noregi og tók myndir af hvalskurðarmönnum danska fyrirtækisins Det danske Fiskeriselskab sumarið 1866. ${ }^{23}$ Iðnvæðing hvalveiðanna var langt á undan vélvæðingu annarra atvinnugreina á Íslandi. ${ }^{24}$ Talsverður fjöldi ljósmynda hefur varðveist frá stórhvalveiðitímabilinu á Íslandi. Mörg dæmi eru um að ljósmyndun tengist hvalveiðistöðvunum beint, enda voru pað bandarískir, danskir, hollenskir og norskir útgerðarmenn sem

19 Konungs skuggsjá. Speculum Regale, Magnús Már Lárusson bjó til prentunar, Reykjavík: Leiftur, 1955, bls. 31.

20 James Elkins, „Art History and Images That Are Not Art“, The Art Bulletin, 77: 4/1995, bls. 553-571.

21 Um merkingu ad vivum í listsögulegu samhengi sjá: Claudia Swan, „Ad vivum, naer het leven, from the life. Defining a Mode of Representation, "Word and Image, 4/1995, bls. 352-372. Sótt 14. september af https://www.tandfonline.com/doi/abs/ 10.1080/02666286.1995.10435926.

22 Eggert Ólafsson, Ferðabók Eggerts Ólafssonar og Bjarna Pálssonar um ferðir peirra á Íslandi árin 1752-1757, Reykjavík: Bókaútgáfan Örn og Örlygur, 1975. Frumútgáfa í Sórey, 1772.

23 Smári Geirsson, Stórbvalaveiðar við Ísland til 1915, bls. 85. Myndir Sigfúsar Eymundssonar eru varðveittar í Pjóðminjasafni Íslands.

24 Smári Geirsson, bls. 66. 
reistu hvalveiðistöðvarnar og byggðu nokkuð fjölmenna péttbýliskjarna á Vestfjörðum og Austurlandi og peir mynduðu starfsemina. Hvalveiðisamfélögin drógu til sín ýmsa gesti. Til að mynda dvaldist danski rithöfundurinn, leikarinn og ljósmyndarinn Johan Holm-Hansen (1841-1920) í hvalstöðinni í Vestdalseyri í Seyðisfirði sumarið 1867 og tók ljósmyndir á Austfjörðum, í Reykjavík og víðar um land. ${ }^{25}$

Með pví að skoða hvalveiðarnar sem eitt af birtingarformum olíumenningarinnar sem einkenndi pjóðfélagsgerð tuttugustu aldarinnar, pá opnast sár sem afhjúpar vistfræðilegt tráma í ljósmyndum hvalstöðvanna. Dæmi um slíkar tilfinningar má finna í myndum sem voru teknar á Asknesi í Mjóafirði skömmu eftir aldamótin 1900. Pær sýna blóðugan hvalskurð á flensiplaninu, rjúkandi bræðslukúta, sundurskorna, risavaxna líkama hvalanna, skíði peirra í haugum, bein og ýmsa líkamsparta dreifða eins hráviði i kring um stöðina. ${ }^{26}$

Ljósmyndirnar sem varðveist hafa frá hvalveiðistöðvunum sem reistar voru víða um land, vekja pví ekki lengur aðdáun á framkvæmdasemi erlendra útgerðarmanna, heldur vitund um pað vistfræðilega hrun sem hvalveiðarnar höfðu í för með sér. Ég mun setja ljósmyndirnar undir smásjá lífvaldsins, sem samkvæmt skilgreiningu Michel Foucaults er „sú tegund valds sem samhæfir félagslegt líf innanfrá, fylgir pví, túlkar pað, gleypir pað í sig og endursegir pað.“27 Pegar ljósmyndirnar eru skoðaðar út frá sjónarhorni sem lýsa mætti sem sakbitinni olíueftirsjá (e. petro-melancholia), pá birtist í peim tilfinning sem lýsa mætti sem umhverfissorg, sem einkennir fagurfræðileg viðmið og reynsluheim okkar samtíma. ${ }^{28}$ Sektarkenndin er einnig skugginn í verkum Magnúsar Sigurðarsonar, en pau verða rædd út frá gagnrýni hans á blætisvæðingu hvalsins Keikó í íslenskri og bandarískri afpreyingarmenningu.

\section{Umbyggjusiðfreði i mynd}

Priðjudaginn 27. ágúst 2019 birtist mynd á forsíðu Fréttablaðsins af hvalreka í Káravík við Seltjarnarnes. Myndin sýnir grindhval sem marar í hálfu

25 Inga Lára Baldvinsdóttir, Ljósmyndarar á Íslandi 1845-1945, Reykjavík: Pjóðminjasafn Íslands og JPV útgáfa, 2001, bls. 230; Smári Geirsson, Stórbvalaveiðar við Ísland til 1915 , bls. 82.

26 Smári Geirsson, bls. 284-285. Myndirnar eru varðveittar í Pjóðminjasafninu. Lpr5781-3, Pjóðminjasafn, 1906-1911, sóttar 30. ágúst 2019 af https://sarpur.is/Adfang.aspx?AdfangID=767288 og Lpr-5781-4, Pjóðminjasafn, 1911 af https://sarpur. is/Adfang.aspx?AdfangID=767299.

27 Michael Hardt og Antonio Negri, „Lífpólitísk framleiðsla“, hér bls. 157.

28 Stephanie LeMenager, „The Aesthetichs of Petroleum, after Oil!“, American Literary History, 24: 1/2012, bls. 59- 86. 
kafi í öldurótinu. ${ }^{29}$ Svartur, gljáandi líkami dýrsins er umkringdur fjórum hjálparsveitarmönnum, klæddum litríkum rauðum björgunargöllum, appelsínugulum vestum, og með gula hjálma á höfði. Allir snerta peir dýrið og að minnsta kosti einn peirra er berhentur. Sá sem er lengst til hægri á myndinni, snýr andlitinu frá sjávarlöðrinu, augu hans eru lokuð, og svört hanskaklædd hönd hans prýstir fast á líkama hvalsins. Myndin sýnir einbeitinguna í andliti mannsins, við skynjum pungann af dýrinu í öldurótinu og nemum um leið samband björgunarsveitarmannanna við hvalinn einmitt á pví augnabliki sem peir beita öllu afli til að ýta dýrinu út á meira dýpi.

Í myndatexta segir:

Björgunarsveitarmenn unnu hörðum höndum að björgun hvals í fjörunni við Eiðsgranda í gær. Fyrst sást til hvalsins snemma morguns í fjörunni á móts við Eiðstorg en hann hafði villst pangað. Hvalurinn var um priggja metra langur, af ættkvísl grindhvala og að öllum líkindum var um ungt karldýr að ræða. Hvalurinn var lemstraður og virtist bæði áttaviltur og ringlaður. Hann var aflífaður af Landhelgisgæslu Íslands á sjötta tímanum að ráði Matvælastofnunar og í kjölfarið sökkt. ${ }^{30}$

Fréttaljósmyndir höfða til ótta mannsins við hið ókunna og sýna iðulega baráttu hans við náttúruöflin eða aðstæður sem hann ræður ekki við. Pær kveikja háleitar tilfinningar sem heimspekingurinn Edmund Burke lýsti á pann veg að „[a]llt pað sem vekur hugmynd um sársauka og hættu, pað er að segja allt sem á einhvern hátt er ógnvænlegt [...], er uppspretta hins háleita; pað er að segja kallar fram sterkustu kenndir sem hugurinn á til.“31

Forsíðumynd Stefáns Karlssonar af atburðinum við Eiðsgranda er athyglisverð pví hún sýnir alveg ný viðbrögð manna við hvalreka. Eins og í góðri

29 Sjá einnig frétt með myndbandi á vefsíðu RÚV 26. ágúst 2019. Dagný Hulda Erlendsdóttir, „Bjarga grindhval við Seltjarnarnes“. Sótt 27. ágúst 2019 af https:// www.ruv.is/frett/bjarga-grindhval-vid-seltjarnarnes.

30 Stefán Karlsson, Fréttablaðið, 27. ágúst 2019, forsíða. Sótt 27. ágúst 2019 af https:// timarit.is/page/7104256?iabr=on\#page/n0/mode/2up. Fleiri ljósmyndir Stefáns Karlssonar af atburðinum birtust í vefútgáfu Fréttablaðsins 26. ágúst 2019. Kristlín Dís Ingilínardóttir, „Grindhvalurinn á Seltjarnarnesi aflífaður af Landhelgisgæeslunni”, Fréttablaðið 26. ágúst 2019. Sótt 27. ágúst 2019 af https://www.frettabladid. is/frettir/grindhvalurinn-a-seltjarnarnesi-aflifadur-af-lanhelgisgaeslunni/.

31 Edmund Burke, A Philosophical Enquiry into the Origin of Our Ideas of the Sublime and the Beautiful, ritstj. Adam Phillips, Oxford: Oxford University Press, 1998 [1757], bls. 36, [pýð. mín]. Sjá einnig: Jennifer Good og Paul Lowe, Understanding Photojournalism, London \& New York: Bloomsbury Academic, 2017, bls. 142. 
hefðbundinni fréttaljósmynd, pá dregur ljósmyndarinn athygli áhorfandans að dramatísku augnabliki atburðanna og sýnir átökin í hita leiksins. Öllum aukaatriðum sem gætu dregið úr áhrifamætti myndarinnar er ýtt út fyrir rammann. Áhorfandi greinir ekki nákvæmlega hversu langt frá landi myndin er tekin eða hvort einhverjir vegfarendur hafi fylgst með átökunum. Slíkar upplýsingar myndu draga úr styrkleika myndarinnar, eins og raun ber vitni pegar myndin er borin saman við fréttaskot á vefsíðu $R U ́ V$ sem voru tekin af sama atburði. ${ }^{32}$

Hér stendur áhorfandinn frammi fyrir ógnvekjandi aðstæðum. Björgunarsveitarmenn leggja líf sitt í hættu til að bjarga hvalnum. Kaldur sjórinn nær peim vel upp í nára og hvítt sjávarlöðrið frussast yfir pá. Eiginleiki ljósmynda er að frysta augnablikið og myndin sem slík segir í raun lítið um ástand hvalsins né greinir hún orsökina fyrir vonlausri stöðu hans í fjöruborðinu, en blóði drifið yfirborð sjávarins sýnir að hér er um líf og dauða að tefla.

Franski táknfræðingurinn Roland Barthes greindi áhrif ljósmynda annars vegar í studium og hins vegar í punctum. Pannig gerði hann greinarmun á ljósmyndum sem vekja almennan áhuga á sögulegum forsendum og peim sem vekja upp sterkar tilfinningar og afhjúpa jafnvel djúpan ótta einstaklingsins eða bældar minningar. Heimilda- og fréttaljósmyndir eru studium, pær miðla upplýsingum og bæta sögulega og samfélagslega pekkingu auk pess sem pær túlka yfirleitt ákveðna menningarbundna sýn á atburði og umhverfi. Sumar fréttamyndir búa auk pess yfir mun sterkari tilfinningalegri merkingu og kveikja nýjan skilning á viðfangsefninu sem sýnt er á myndinni. Slíkar myndir vekja sársauka, eða sting, sem truflar heildarsvip myndarinnar og pau áhrif kallaði Barthes punctum..$^{33}$ Í pessu tilviki er punctum myndarinnar hvorki blóðið á haffletinum né skærir búningar hjálparsveitarmannanna, heldur snertingin, svört hanskaklædd hönd björgunarsveitarmannsins sem prýstir á líkama dýrsins og sýnir umhyggju hans fyrir verkefninu og sterka samkennd með hvalnum.

Hvalreki vekur ætíð athygli almennings og svo margir hvalrekar á stuttum tíma kveiktu spurningar fjölmiðla til vísindamanna um stöðu rannsókna á hvalastofnum í Norðurhöfum og peim flóknu áhrifum sem hvalaskoðunarbátar og heræfingar neðansjávar gætu hugsanlega haft á lífsgrundvöll hvala. ${ }^{34}$ Mynd Stefáns mætti pví túlka á umhverfissiðfræðilegum forsendum

32 Dagný Hulda Erlendsdóttir, „Bjarga grindhval við Seltjarnarnes“.

33 Roland Barthes, La chambre claire. Note sur la photographie, Paris: Gallimard, 1980, bls. 49.

34 Sjá fyrirspurn Andrésar Inga Jónssonar, alpingismanns, til Kristjáns Pórs Júlíussonar 


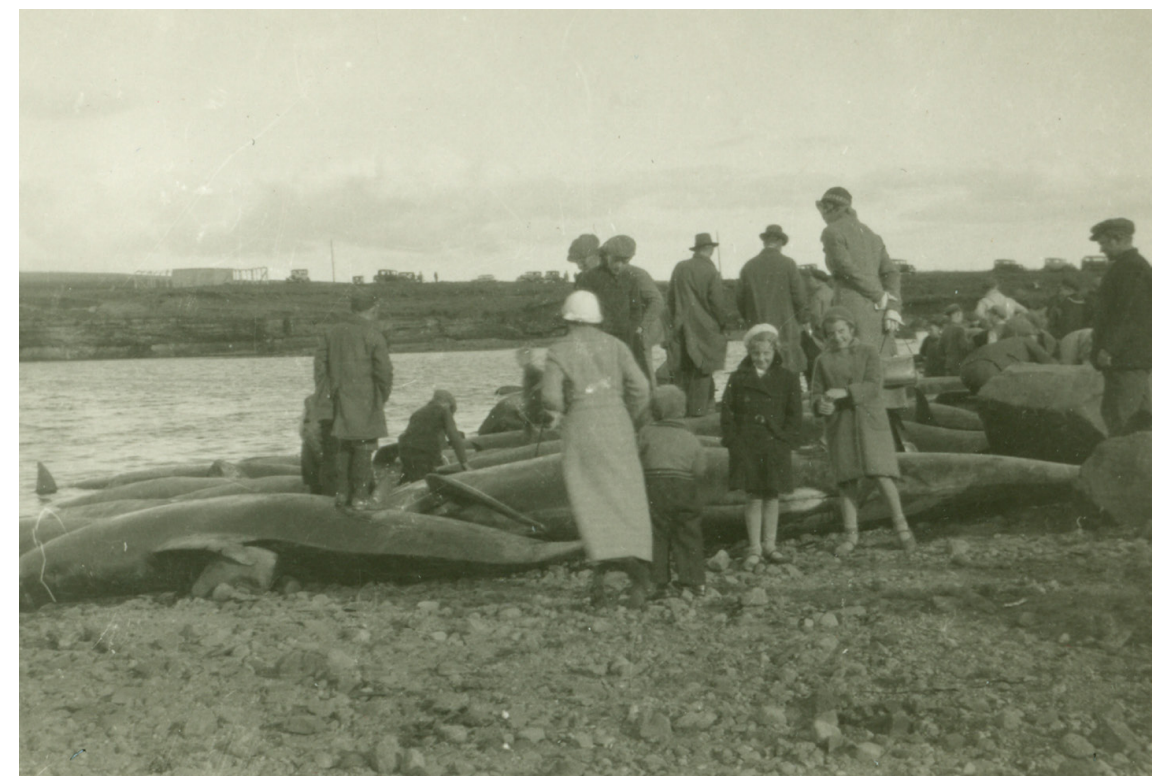

Alfreð Dreyfus Jónsson (1906-1994), Hvalreki i Fossvogi, 1934. Pjóðminjasafn Íslands.

pví líf hvalsins er hluti af manngerðri veröld. Umhyggjurýmið (e. care space) nær til hvalsins í flæðarmálinu á pessum óljósu mörkum borgar og náttúru. ${ }^{35}$ Hvalurinn parf á vernd að halda og í stað pess að leggja áherslu á sigur karlmennskunnar yfir dýrinu eins og gert var í eldri myndum af hvalreka á svipaðan hátt og í hefðbundnum veiðimyndum, pá varpar ljósmyndarinn ljósi á vonlausar aðstæður hvalsins og bendir á hvernig björgunarsveitarmennirnir unnu störf sín á forsendum hans.

Pannig sýnir ljósmyndarinn ábyrgðarfullt samband manns og náttúru með pví að leggja áherslu á tilraun til björgunar fremur en slátrunar. Myndin stingur pví í stúf við ljósmyndir sem voru teknar við svipaðar aðstæður, eins og pegar hjörð marsvína rak á land í Fossvogi árið 1934. Pá vappaði forvitinn hópur prúðbúins fólks í kring um hvalina á meðan aðrir menn skáru pau í flæðarmálinu. ${ }^{36}$

sjávarútvegsráðherra. Sótt 10. september 2019 af https://www.althingi.is/altext/ 150/s/0562.html.

35 Um umhyggjusiðfræði sjá: Maurice Hamington, Embodied Care. Fane Addams, Maurice Merleau-Ponty, and Feminist Ethics, University of Illanois, 2004, einkum bls. 1-8.

36 Alfreð Dreyfus Jónsson, Hvalreki i Fossvogi, 1934. ADJ3-120, Pjóðminjasafn Íslands. 


\section{Myndboð valdsins}

Hvalir koma víða við sögu í Íslendingasögum og flestir pekkja frásögnina um hvalreka í Grettis sögu sem endaði með blóðugum bardaga um kjötið. ${ }^{37}$ I fornaldarsögum er líka svæsin lýsing á pví pegar Ketill hængur fann mikið magn af hvalkjöti, hvítabjarnakjöti, „selum ok rostungum og alls konar dýrum“.38 Íslendingar og Norðmenn byggðu pekkingu sína á hvölum á reynslunni og mörg hvalanöfn eiga rætur að rekja til lýsinga á ólíkum tegundum í Konungs skuggsjá, sem er skrifuð um $1250 .{ }^{39}$ Ritið hefur einnig að geyma ýmsan fróðleik um hvali, seli og rostunga, auk furðusagna um hin ýmsu hafskrímsli, svo sem hafstömbu sem var með mannsandlit og svo mikil vexti að hún gat staðið upprétt úr hafinu. ${ }^{40}$ Sagt er að hvalateikningar í Konungs skuggsjá hafa máðst út, en hugsanlega hefur verið um útlínuteikningar að ræða, pótt erfitt sé að geta sér til um pað.

Elstu myndir sem sýna hvalreka og hvali hafa varðveist í fónsbókarbandritum frá fjórtándu öld. Myndirnar eru allar teiknaðar inn í pröngan og aflokaðan belg upphafsstafsins „h“í rekapætti fónsbókar, par sem segir af reglum um hvalskurð og hvernig hvalreka skuli skipt. Lýsing í handriti AM 127 4to sýnir tvo menn skera frekar smávaxið dýr sem af útlitinu að dæma virðist vera selur. Dýrið hefur bægsli, eða framhreifa, tvo afturhreifa, stór augu, dökkar nasaholur, opinn munn og greinilegt skegg í kringum munninn. Раð liggur frekar klunnalega á bylgjulaga mynstri sem táknar að skurðurinn á sér stað í flæðarmálinu. ${ }^{41}$

Önnur teikning sýnir prjá karla umkringja smáhveli af óljósri tegund. Einn mannanna brýnir sveðju á meðan sá í forgrunni beygir sig yfir dýrið til að skera af pví bægslin. Sá priðji bíður átekta með sveðjuna á lofti. Á myndinni má einnig greina öldur undir dýrinu sem tákna hafið, enda sögðu lögin til um að hvalskurðinn ætti að framkvæma á ströndinni. ${ }^{42}$

Á priðju myndinni, sem er að finna í Skarðsbók fónsbókar, fer ekki á milli mála að um stóran hval er að ræða. Skarðsbók er talin með fegurstu hand-

Grettis saga Ásmundarsonar. Íslensk fornrit, 7. bindi, Reykjavík: Hið íslenska fornritafélag, 1936, bls. 29-30.

38 „Ketils saga hængs“, Fornaldarsögur Norðurlanda, II. bindi, Reykjavík: Íslendingasagnaútgáfan, 1950, bls. 149-181, hér bls. 155-156.

39 Vicki Ellen Szabo ræðir hvalabálk Konungs skuggsjár í Monstrous Fishes and the MeadDark Sea, bls. 181-191.

40 Konungs skuggsjá. Speculum Regale, bls. 52.

41 AM 127 4to.

42 Gl. Kgl. Sml. 3269 a 4to. 


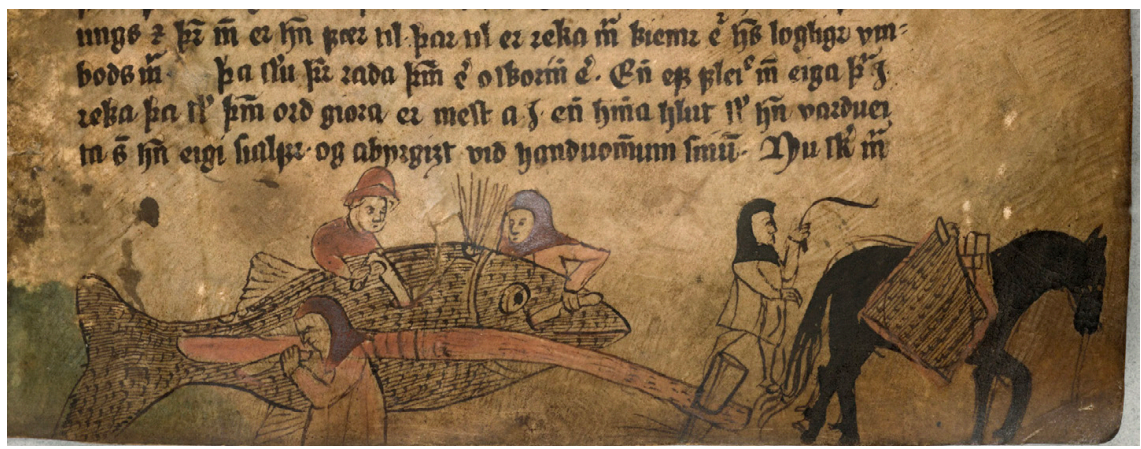

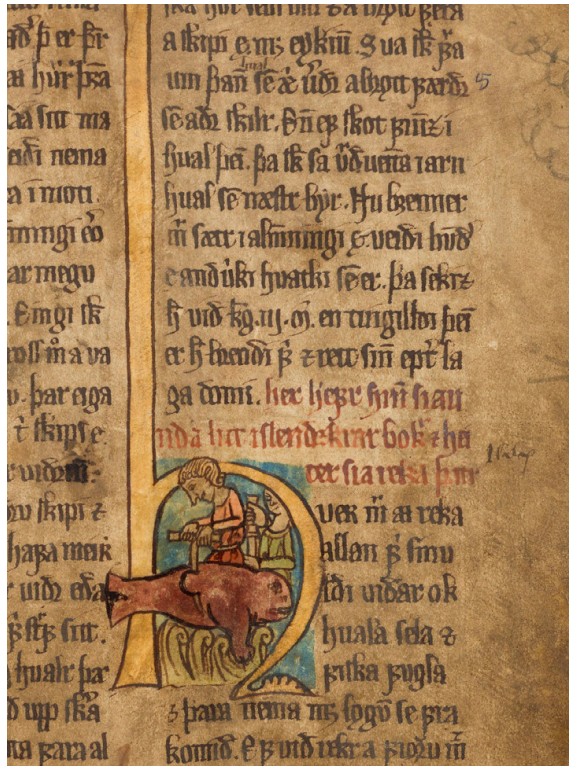

Fónsbókarbandrit frá síðari hluta 16. aldar. AM

345 fol. Stofnun Árna Magnússonar í íslenskum fræðum. Ljósmyndari: Sigurður Jónsson. (efst)

Fónsbókarbandrit frá 14. öld. AM 127 4to.

Stofnun Árna Magnússonar í íslenskum fræðum. Ljósmyndari: Sigurður Jónsson. (miðja t.v)

Fónsbókarbandrit frá 14. öld. Gl. Kgl. Sml. 3269 a 4to. Stofnun Árna Magnússonar í íslenskum fræðum. Ljósmyndari: Sigurður Jónsson. (miðja t.h)

Skarðsbók fónsbókar, 14. öld. AM 350 fol, blað 51r. Stofnun Árna Magnússonar í íslenskum fræðum. Ljósmyndari: Sigurður Jónsson. (t.h.)

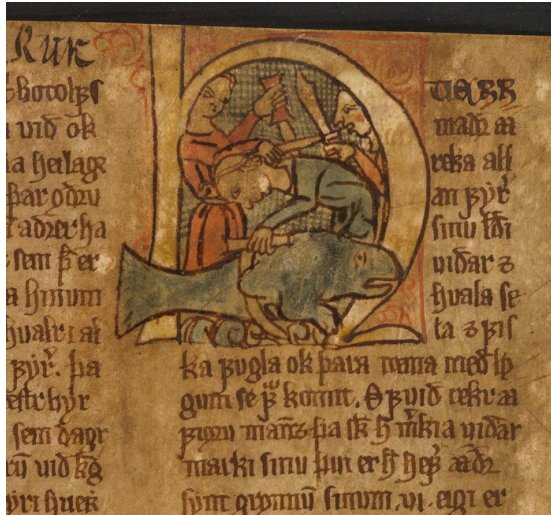

\begin{tabular}{|c|c|}
\hline 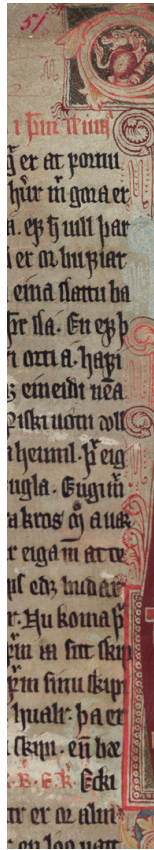 & 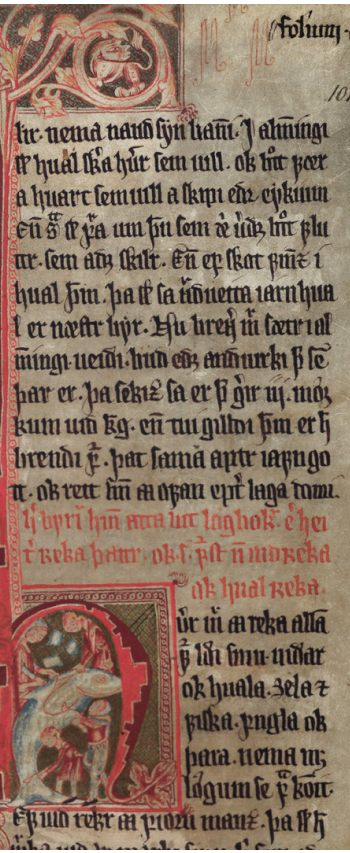 \\
\hline
\end{tabular}


rita og teikningin er mun fínlegri og nákvæmari en hinar tvær. Hvalurinn myndar fagran sveig inni í bug upphafsstafsins „h“, en liggur ekki klunnalega við fætur skurðarmannanna eins og á hinum myndunum. Hann er umkringdur fjórum karlmönnum sem skera dýrið, en pað er mun stærra en peir sjálfir. Hver og einn einbeitir sér að ákveðnum hluta pess, en sá sem stendur í forgrunni myndarinnar virðist vera elstur og sker bægslin. ${ }^{43}$

Fjórða myndin, sem hér er fjallað um, er frábrugðin hinum pví um er að ræða neðanmálsteikningu í fónsbókarbandriti frá sextándu öld. ${ }^{44}$ Prír menn skera hvalinn og sá fjórði flytur kjötið burt á hesti. Áhorfandinn er dreginn inn í ákveðna atburðarás pví hér er greint á milli hvernig hvalurinn er festur, skorinn og kjötið flutt af vettvangi. Sá sem sker bægslin er rauðklæddur með hatt, hinir í grófum mussum með svartar hettur á höfði. Jafnvel pótt myndbyggingin sé flóknari en í eldri myndunum, pá virðist teiknarinn ekki byggja á reynslunni og dregur dýrið upp eins og pað væri stór fiskur. Gjósandi öndunaropið sést samt greinilega á baki dýrsins, eins og tákn um að hér sé um hvalfisk að ræða.

Pótt handritalýsingarnar séu gerðar af mismikilli nákvæmni og ólíkum hagleik, pá hafa teiknararnir lagt sig fram um að líkja eftir útlitseinkennum dýranna og gætt að stærðarhlutföllum peirra. Allir sýna peir að skurðurinn er samvinnuverkefni, athöfn, par sem farið er eftir ákveðnum fyrirfram settum reglum. Myndirnar eiga pað sameiginlegt að sýna augnablikið pegar einn mannanna beygir sig yfir dýrið til að skera af pví bægslin. Valdið parf að sýna og á miðöldum höfðu yfirvöld ákvörðunarrétt yfir lífi og dauða. Hér virðist reglugerðin um hvalskurðinn og yfirburðir mannsins yfir dýrinu skipta meira máli en lýsing á umhverfinu eða á tilteknum atburði.

Karlmennirnir bera allir persónueinkenni sem eru túlkuð með mismunandi fatnaði, hárgreiðslu og svipbrigðum. Á klæðnaði peirra má greina að peir eru af ólíkri stöðu eða stétt. Petta eru ekki frumstæðir veiðimenn, heldur skipuleggja peir skurðinn samkvæmt lagabókstöfum og beita ólíkum verkfærum, sveðjum og hvalajárnum, af kunnáttu við sundurlimun dýrsins samkvæmt fyrirfram ákveðnum reglum.

Hvalamyndirnar í fónsbókarbandritunum sýna pví ögun líkamans og regluverk valdsins (svo vísað sé í orðræðu Michel Foucault). Pær mætti túlka sem beina áminningu um umráðavald mannsins yfir náttúrunni. Karlmenn-

43 Skarðsbók fónsbókar AM 350 fol, blað 51r. Vicki Ellen Szabo lýsir pessum myndum nokkuð nákvæmlega í bók sinni Monstrous Fishes and the Mead-Dark Sea, bls. 271-273.

44 AM 345 fol, blað 51r. Sótt 10. október 2019 af https://handrit.is/en/manuscript/ imaging/is/AM02-0350\#page/50v++(112+of+350)/mode/2up. 
irnir eru sýndir í hlutverki stjórnenda, á meðan hvalurinn liggur hreyfingarog áhrifalaus við fætur peirra.

\section{Hvalurinn á landakortinu}

Markmið lífvaldsins var að auka getu og framleiðni einstaklinga og tengdist pví uppgangi kapítalisma í Evrópu. Landakortum og náttúrulýsingum, ritum um dýrafræði tók mikið að fjölga á seinni hluta sextándu aldar. Pau eru gott dæmi um pekkingar- og myndsköpun sem hafði pað að markmiði að auka útpenslu, færni og framleiðni.

Landakort sextándu aldar rúma bæði lýsingu á landfræðilegum einkennum og menningarlegum frásögnum, sem lýsa umhverfinu á mörkum reynslu og ímyndunar. Nöfn á hvölum, eiginleikum peirra, og góðu eða illu innræti, byggðu á texta Konungs skuggsjár, en par er enginn tegundamunur gerður á milli hvala og sjóskrímsla, rostunga og fiska. Hrosshvalur og rauðkembingur eru sagðir fullir af ,ágirnd og illsku. Aldrei verða peir saddir af manndrápum, pví að peir fara um öll höf innan og leita, ef peir mega skip finna. “45

Pannig var heimsmyndin dregin upp á milli reynslu og pjóðsagna. Hún endurspeglar spennuna á milli peirra náttúrufyrirbæra sem maðurinn óttaðist og peirrar náttúru sem maðurinn taldi sig bekkja og vera að ná valdi yfir. Pessi óvissa birtist í Carta marina sem áður er minnst á, landakortinu sem var fyrirmynd að Íslandskortinu fræga sem kennt er við Guðbrand Porláksson, gefið út af flæmska kortagerðarmanninum Abraham Orteliusi í atlasi hans Theatrum Orbis Terrarum árið 1585.

Hvalirnir og önnur sjávardýr skrímslin og ormarnir sem umkringja landið á Orteliusarkortinu hafa ólíkum hlutverkum að gegna í hafinu. Mörg peirra eru blendingar, goðsöguleg dýr, eins og hrosshvalur, sem er hestur að framan og fiskur að aftan. Einnig má greina á kortinu raunsæislegri teikningar, af rostungi (sem reyndar var lengi talinn vera karlkyns hvalur), hafís og rekaviði, ásamt mynd af búrhvali, sem sagður er góður til átu og með sterkar tennur sem úr megi skera taflmenn. Pannig ægði saman pekkingu og pjóðsögum sem hver tók upp eftir öðrum. Dökkur, distópískur myndheimurinn sem Olaus Magnus dró upp í bók sinni Historia de gentibus septentrionalibus (1555) fór víða pví evrópskir fræðimenn endurtóku furðufrásagnir hans og tilgátur um hvali og sjóskrímsli. Olaus lýsir fiskunum í hafinu, hinum ýmsu undrum og sjávarskrímslum. Hann segir frá pví að fyrir

45 Konungs skuggsjá, bls. 30. 
utan strendur Noregs finnist fiskaskrímsli sem kölluð séu hvalir. ${ }^{46}$ Hann lýsir ógnvænlegu útliti peirra og risti af peim myndir sem birtust í síðari tíma náttúrulýsingum ýmist endurgerðar nákvæmlega eftir hans fyrirmynd eða í breyttum útfærslum.

Talið var að frjósemi hafsins eldi af sér hin undarlegustu skrímsli og pað var pví ekki svo fráleitt að trúa sögum um illhveli sem reyndu að tæla til sín smáfiska með lyktinni einni eða umbreyttu sér í líki eyju til að blekkja sjómenn. Fræg er lýsing Olaus Magnus á pví hvernig íbúar norðursins nýti hvalina til hins ýtrasta. Dýrið væri húðflett, kjötið skorið í stykki, fitan brædd og bein nýtt eða mulin í hinar smæstu einingar. Engu sé kastað á glæ og allt nýtt inn að beini, jafnvel hús séu byggð úr rifbeinum hvalsins og húð hvalsins notuð sem hurð á pessum dýrslegu híbýlum. ${ }^{47}$ Áhrif hvalanna voru í raun svo skæð að pað var ekki nóg með að pau smituðust inn í hugarheim og daglegt líf íbúanna á norðurslóðum, heldur héldu líkamar peirra og vessar áfram að lifa góðu framhaldslífi eftir dauða peirra í paulnýtingu manna á afurðunum; hvalbeini, olíu, kjöti, spiki og öllu pví sem nýtanlegt var til manneldis og framleiðslu hluta. ${ }^{48}$

Franski landkönnuðurinn André Thevet (1516-1590) var landfræðingur og heimsmyndasmiður Frakkakonungs, François I. Hann birtir raunsæislega tréristu af hópi manna að flensa hval í bók sinni Cosmographie Universelle (1575). Nokkrir karlmenn standa á baki hvalsins á meðan aðrir hafa tréilátin klár undir lýsið, en í baksýn sést hvalur ráđast á skip og önnur illhveli fylgjast með sjómönnum. ${ }^{49}$ Myndin ber yfirbragð hvalamyndanna á Carta marina, og virðist hún að hluta til vera samsett úr fyrirmynd Olausar.

Myndir af fiskibiskupi, skrímsli sem átti að hafa fundist í Noregi, sem var blendingur með fætur og mannsandlit, voru vinsælar. Pær birtust í fiskafræði

46 Olaus Magnus, A Description of the Northern Peoples, Rome 1555, ritstj. Peter Foote, London: The Hakluyt Society, 1998, bindi. III, bók 21, bls. 1086.

47 Olaus Magnus, A Description of the Northern Peoples, Rome 1555, bls. 1107. Sjá einnig: Vicki Ellen Szabo, Monstrous Fishes and the Mead-Dark Sea, bls. 196-210; Vicki Ellen Szabo, "Bad to the bone"? The Unnatural History of Monstrous Medieval Whales", The Heroic Age. A Journal of Early Medieval Northwestern Europe 8/2005. Sótt 4. nóvember 2019 af http://www.heroicage.org/issues/8/szabo.html.

48 Vicki Ellen Szabo, Monstrous Fishes and the Mead-Dark Sea, bls. 196-210; Vicki Ellen Szabo, "Bad to the bone”? The Unnatural History of Monstrous Medieval Whales", The Heroic Age. A Journal of Early Medieval Northwestern Europe 8/2005. Sótt 4. nóvember 2019 af http://www.heroicage.org/issues/8/szabo.html.

49 Myndina má skoða á vefslóð https://gallica.bnf.fr/ark:/12148/btv1b2000115n/f136. item. Sótt 10. október 2019. 
Pierre Belon (1517-1564) og hjá Guillaume Rondelet (1507-1556). ${ }^{51}$ Fiskafræði hans var samt gerð af mikilli nákvæmni og einkennilegt að hann skuli fella slíkt skrímsli inn í frásögn sem var að öllum líkindum skrifuð sem leiðarvísir um hvaða fiska kapólskir menn mættu leggja sér til munns á föstunni.

Pá felldi svissneski læknirinn og náttúrufræðingurinn Conrad Gessner (1516-1565) skrímslamyndir Olaus Magnus inn í fjórða hluta yfirlitsritsins Historia animalium. ${ }^{52}$ Rit Gessners var tilraun til að taka saman í eitt náttúrufræðirit allt pað sem hafði verið skrifað (og teiknað) um dýr jarðarinnar. Í formála bendir Gessner á hversu mikilvægt pað sé að sýna myndir af dýrum pví almenningur geti sjaldnast nálgast pau, auk pess sem sum geti verið afar hættuleg. Hann byggði tegundaflokkunina á skrifum peirra Belons (De Aquatilibus, 1553 og La nature et diversité des poissons, 1555), fiskafræði Rondelets (Libri de piscibus marinis, 1554), auk pess sem hann studdist við áðurnefnd rit Olaus Magnusar og nýtti myndefni hans í kafla sem er tileinkaður hvölum og sjávarskrímslum. ${ }^{53}$ Hann ræðir útlit dýranna, gerir grein fyrir heimkynnum peirra, hegðun og skaplyndi, auk pess sem hann tekur saman ýmsan annan fróðleik, segir frá dýraafurðum og nýtingu peirra í matargerð og til lækninga. Gessner ræðir trúverðugleika myndanna sem eigi sér ólíkar fyrirmyndir og séu yfirleitt ekki gerðar ad vivum. Рað merkir að myndirnar séu ekki byggðar á reynslunni af lifandi dýrum, né teiknaðar eftir dauðum dýrum, heldur endurgerðar eða samsettar eftir eldri myndum og pví séu dýrin ekki alltaf sýnd í réttum stærðarhlutföllum. Sumar myndirnar í bókinni eru pó allraunsæislegar, eins og teikningin af nýborinni háhyrningskú með kálfi, en myndina fékk hann úr riti Belons. ${ }^{54}$ Gessner vísar einmitt til samsvörunar hvala við landdýr pví peir séu með lungu, nýru, pvagblöðru,

50 Pierre Belon, L'bistoire naturelle des estranges poissons marins, avec la vraie peincture et description du daulphin, et de plusieurs autres de son espèce, $1551 \mathrm{og}$ La Nature et diversité des poissons, avec leurs pourtraicts représentez au plus près du naturel, en 1555. Sótt 10. október 2019 af https://archive.org/details/petribelloniicen00belo/page/39/mode/2up.

51 Guillaume Rondelet, Histoire entier des poissons, Lyon: Macé Bonhomme, 1558. Sótt 10. október 2019 af https://gallica.bnf.fr/ark:/12148/bpt6k1512044f/f1.planchecontact.

52 Sachiko Kusukawa, "The sources of Gessner's pictures for the Historia animalium“, Annals of Science 67: 3/2010, bls. 303-328, hér bls. 310.

53 Sophia Hendrikx, „Monstrosities from the Sea. Taxonomy and tradition in Conrad Gessner's (1516-1565) discussion of cetaceans and sea - monsters“, Anthropozoologica, 53: 11/2018, bls. 125-137, hér bls. 126-127. Sótt 14. október 2019 af https:// doi.org/10.5252/anthropozoologica2018v53a11.

54 Myndina má sjá á vefslóðinni https://archive.org/details/petribelloniicen00belo/ page/18/mode/2up. Sótt 14. október 2019. 
eistu, kynfæri, eggjastokka og geirvörtur og geti og fæði afkvæmi sín á sama hátt og pau. ${ }^{55}$ Hann endursegir líka furðusöguna um fiskibiskupinn, ekki vegna pess að sagan sé trúverðug, heldur vegna pess að slíkar sögur væru hluti af hugmyndaheimi manna. Gessner úthýsti pví ekki eldri pekkingu en skapaði sína eigin aðferðarfræði sem byggði á pví að draga saman í einskonar gagnagrunn fjölfræðilegar upplýsingar um hvert dýr fyrir sig par sem öllum upplýsingum og fróðleiksmolum var haldið til haga innan kerfisins. ${ }^{56}$

Pjóðsögur um skrímsli lifðu pví áfram góðu lífi samhliða tilraunum til að byggja upp víðtækari reynslupekkingu á dýrum og náttúrulegu umhverfi peirra. Myndir og bein voru mikilvæg sönnunargögn, en að sama skapi var náhvalstönn talin vera horn einhyrningsins og lengi var bannað að eta pá hvali sem voru taldir illa innrættir. Miðaldafræðingurinn Vicki E. Szabo telur að pessi annarleiki eða öðrun dýrsins hafi haft áhrif á afstöðu manna til hvala (og til hvalveiða) og geti hugsanlega skýrt hversu grimmdarlegar aðfarirnar gátu verið við hvalskurðinn. Hún bendir á að andúð og togstreita á milli kapólsku og lútersku kirkjunnar á sextándu öld birtist í frásögnum af sjávarskrímslum sem sumum voru gefin pessi ímynduð nöfn, heimfærð upp á kirkjunnar menn, eins og monachus marinus og episcopus marinum eða fiskibiskup. Pví mætti einnig velta fyrir sér hvort óræð staða hvala sem dýra eða skrímsla, fiska eða spendýra hafi ýtt undir pessar skopstældu myndhverfingar. ${ }^{57}$

\section{Náttúrufreði i furdukamesi}

Fyrir tæplega 500 árum, eða pann 24. nóvember árið 1520, skrifaði pýski listamaðurinn Albrecht Dürer (1471-1528) í dagbók sína: „Við Zierikzee á Zeelandi skolaði hval á land í stormi og stórflæði. Hann er miklu meira en hundrað faðma langur, [...] íbúar myndu gjarnar vilja losna við hann pví peir óttast fnykinn. ${ }^{“ 58}$ Dürer var pá á löngu ferðalagi um Niðurlönd og upp-

${ }_{55}$ Sophia Hendrikx, „Monstrosities from the Sea“, bls. 126.

${ }^{56}$ Laurent Pinon, „Conrad Gessner and the Historical Depth of Renaissance Natural History", Historia: Empirism and Erudition in Early Modern Europe, ritstj. Gianna Pomata og Nancy Sisaisi, Cambridge MA og London: MIT Press, 2005, bls. 241-267, hér bls. 248-249.

57 Vicki E. Szabo, „"Bad to the bone”? The Unnatural History of Monstrous Medieval Whales", bls. 133.

${ }^{58}$ Dürer lagði upp frá heimabæ sínum Nürnberg pann 12. júlí 1520 ásamt konu sinni og pjónustustúlku. Tilgangur ferðarinnar var m.a. að vera viðstaddur krýningu Karls V til konungs í Aachen 23. október 1520, en Dürer mótaði andlit hans í silfurpening. Ferðin tók heilt ár og hann sneri aftur heim í júlí 1521, protinn kröftum 
lýsingarnar um hvalrekann hafði hann eftir frásögnum. Hvalreki var mikið sjónarspil og menn stóðu furðu lostnir frammi fyrir fiski (eins og hvalir voru pá flokkaðir) sem átti kálfa og mjólkaði. ${ }^{59}$ Listamaðurinn lagði pví á sig langa og erfiða ferð í gegnum Middelburg og Arnemuiden, sem hann lýsir í dagbókinni. Pegar hann nálgaðist áfangastað pá frétti hann að hvalnum hefði skolað á haf út.

Dürer var endurreisnarmaður og hafði lítinn áhuga á skálduðum dýramyndum miðalda (bestiaries) og siðferðilegri merkingu peirra. Löngun hans til að sjá og teikna hvalrekann verður að setja í samhengi við mynd sem hann teiknaði af nashyrningi nokkrum árum áður. Nashyrningurinn var fluttur frá Indlandi til Portúgal árið 1513 og sýndur víða í Evrópu. Dürer sá hann heldur aldrei, en teiknaði dýrið eftir eftir bestu vitund og studdist við skriflega lýsingu og einfalda skissu, en samt varð prentmynd hans af nashyrningnum mikilvæg fyrirmynd sem fór víða og var lengi notuð sem sönn mynd af dýrinu í náttúrulýsingum og dýrafræðiritum. ${ }^{60}$

Listamenn reyndu að nálgast hvali og önnur sjaldgæf dýr sem bárust til Evrópu til að teikna pau með berum augum og gera af peim eftirsóttar prentmyndir. Раð var mikið í húfi pví myndir sem voru gerðar eftir lifandi eða dauðum fyrirmyndum voru verðmætur vitnisburður sem byggðu á reynslu af hlutnum. Pær voru gerðar „ad vivum“ og voru pví trúverðugt sönnunargagn og gátu orðið mikilvægar fyrirmyndir prentmynda og góð söluvara. Dürer tókst aldrei að komast í tæri við hval og pví verðum við að ímynda okkur hvernig mynd hans af hvalnum hefði getað orðið. Dagbókarfærsla hans endurspeglar vel samband hans við reynsluheiminn og er jafnframt vitnisburður um pá spennu sem fréttir af hvalreka og sögusagnir af

og veikur af malaríu. Erwin Panofsky, The Life and Art of Albrecht Dürer, Princeton: Princeton University Press, 1955, bls. 10 og 206-207. Sjá einnig Albrecht Dürer, Memoirs of Journeys to Venice and the Low Countries, 1913, bls. 63-64. Sótt 14. september 2019 af https://archive.org/details/recordsofjourney00drer/page/62.

59 Fæðing kálfs er sýnd á mynd í náttúrulýsingu Pierre Belon (1517-1564), L’histoire naturelle des estranges poissons marins, avec la vraie peincture et description du daulphin, et de plusieurs autres de son espèce, $1551 \mathrm{og}$ La Nature et diversité des poissons, avec leurs pourtraicts représentez au plus près du naturel, en 1555. Sjá bls. 39 á vefslóðinni https:// archive.org/details/petribelloniicen00belo/page/39/mode/2up. Sótt 14. september 2019.

60 Craig Ashley Hanson, „Representing the Rhinoceros. The Royal Society between Art and Science in the Eighteenth Century", fournal for Eighteentb-Century Studies 33: 4/2010, bls. 545-566. Sótt 14. september 2019 af https://doi.org/10.1111/ j.1754-0208.2010.00322.x. Sjá einnig Jim Monson, „A Source for the Rhinoceros“, Print Quarterly, 21: 1/2004, bls. 50-53. 
peim kveiktu meðal fólks. Annarleiki hvalanna, stærð peirra og óvissa manna um hvort telja ætti pá til fiska, dýra eða skrímsla gerði pað að verkum að eftirsótt var að komast í snertingu við pá, auk pess sem hvalreki var í flestum tilvikum mikil búbót.

Sjálfur var Dürer safnari og átti verðmætt furðusafn (p. Wunderkammer), sjaldgæf lifandi smádýr, apa og ýmiss konar naturaliae. Hann seldi teikningar sínar og prentmyndir til eins stærsta safnara álfunnar, Rudolfs II (1552-1612), keisara af Habsburg. Dýramyndir Dürers urðu hluti af svokallaðri dýrabók (p. Tierbuch) sem var varðveitt í furðukamesi keisarans í Prag. ${ }^{61}$ Safnið geymdi alskonar sérkennilegar og framandir steintegundir, uppstoppuð og lifandi dýr, fugla og fiska, sjaldgæfa dýrgripi og myndir sem vöktu undrun og forvitni. Teikningar af lifandi fyrirbærum sem ekki var hægt að varðveita, eða fundust eingöngu á framandi slóðum, gegndu hlutverki staðgengils eða „proxy“ í stað lifandi eða dauðs sýnishorns í safninu. ${ }^{62}$

Furðusöfnin voru safn pekkingar, nokkurs konar smáheimur, par sem undrum veraldar var safnað saman á einn stað. Pau eru vitnisburður um undrunina sem bókmenntafræðingurinn Stephen Greenblatt hefur skilgreint sem kjarnann í vinnubrögðum Evrópubúa gagnvart nýrri heimsmynd sextándu aldar. Landakort, prentmyndir og furðusöfn festu rætur og fengu varðveisluhlutverk í samfélaginu, pví pau voru nýtt birtingarform pekkingar á sviði lista og vísinda. ${ }^{63}$

\section{Andspanis bvalnum}

Hvalrekamynd flæmska listamannsins Johannes Wierix (1549-1615) gæti hugsanlega gefið hugmynd um hvalinn sem Dürer vildi teikna. Prentmynd Wierix sýnir prjá strandaða búrhvali og tíu aðra svamla í flæðarmálinu skammt undan Ter Heyden árið 1577. Hvalurinn fremst í myndfletinum er teiknaður af mikilli nákvæmni. Íbúar hópast á ströndina til að virða fyrir sér dýrin á meðan aðrir flýja af vettvangi eins og peir eigi fótum fjör að

${ }_{61}$ Thomas DaCosta Kaufmann, „Remarks on the Collections of Rudolf II. The Kunstkammer as a Form of Representation“, Art fournal, 38: 1/1978, bls. 22-28. Sótt 5. janúar 2020 af https://www.jstor.org/stable/776251.

62 Claudia Swan, „Ad vivum, naer het leven, from the life: defining a mode of representation“, Word \& Image, 4/1995, bls. 353-372, hér bls. 369-371. Sótt 5.janúar af https://www.tandfonline.com/doi/abs/10.1080/02666286.1995.10435926.

63 Stephen Greenblatt, Marvellous Possessions. The Wonder of the New World, Chicago: The University of Chicago Press, 1991, bls. 14. Petta efni er rætt í grein Valdimars Th. Hafstein, „Pekking, virðing, vald: Virtúósinn Ole Worm og Museum Wormianum í Kaupmannahöfn“, Ritið 1/2010, bls 25-57, hér bls. 29. 
launa, hugsanlega vegna fnyks. ${ }^{64}$ Myndin er pví allt í senn nákvæm teikning á líkamseinkennum hvalanna og lýsing á sjónarspilinu í kring um hvalrekann á ströndinni.

Önnur prentmynd frá 1594 eftir Hendrick Goltzius (1558-1617), Hvalreki við Zandvoort, sýnir tvo menn mæla grindhval á meðan hópur fólks streymir að, svo langt sem augað eygir, til að berja dýrið augum. ${ }^{65}$ Fleiri niðurlenskar prentmyndir sýna hvalreka sem furðuverk og sjónarspil. Áhorfendur safnast ætíð í kringum hræin, oft prúðbúnir eða jafnvel af aðalsmannaætt, eins og sést á mynd af hvalreka í nágrenni Beverwijk, nítjánda desember 1601. Í forgrunni, til vinstri, sést listamaðurinn sjálfur, Jan Saenredam (1565-1607), teiknandi atburðinn. Kápa hans skýlir honum fyrir gjólunni á meðan greifinn Ernst Casimir of Nassau-Dietz (1573-1632), fyrir miðju myndarinnar, ber vasaklút að vitum sér. ${ }^{66}$ Fjórir menn standa uppi á baki hvalsins, tveir stinga úr honum augun með sveðju. Nákvæm stærð og hlutföll hvalsins eru skráð á myndina, auk lýsingar á pví pegar hann sprakk vegna gasmyndunar í líffærum hans. Nærvera listamannsins og greifans á ströndinni undirstrikar trúverðugleika myndarinnar. Parna er ekki einungis verið að lýsa sjónarspilinu, heldur er teikningin vitnisburður, nánast fréttamynd um pað sem gerðist. Hún vísar jafnframt til fleiri atburða, pví efst í myndfletinum eru dregnar upp smámyndir sem vísa í plágurnar og náttúruhamfarirnar sem geisuðu í Norður-Evrópu skömmu eftir $1600 .{ }^{67}$ Hamfaramyndir af pessu tagi gegndu pví samtímis hlutverki annáls og samfélagslegrar allegóríu pví pær draga pví upp dökka mynd af atburðunum. ${ }^{68}$ En prátt fyrir að hvalir væru dýrmæt

64 Hægt er skoða myndina á vefsíðu Fine Arts Museums of San Fransisco. Sótt 10. október 2019 af https://art.famsf.org/johannes-wierix/whales-stranding-terheyde-1971296.

65 Prent varðveitt á British Museum. Sótt 10. október 2019. https://research.britishmuseum.org/research/collection_online/collection_object_details.aspx?objectId=1478619\&page= 1 \&partId=1\&peoA=123262-2-60\&people=123262 .

${ }_{66}$ Myndin var gerð árið 1602, en prentað eintak varðveitt í British Museum er frá 1618. Sótt 10. október 2019 af https://www.britishmuseum.org/research/collection_online/collection_object_details.aspx?objectId=1506563\&partId=1.

67 Par má nefna sóttina í Amsterdam veturinn 1601-2, sólmyrkvann 24. desember 1601, jarðskjálftann sem gekk yfir Holland 2. janúar 1602, tunglmyrkva 4. júní, og loks umsátrið við Oestende.

68 Umræddar náttúruhamfarir voru á Íslandi kenndar við Píslarárið. Á Magnúsarmessu var sólmyrkvi, veturinn var kallaður Lurkur. Næsti vetur á eftir var kallaður Píníngarvetur (1601-1602) og fylgdi hungur, sóttir og mannfall. Priðja veturinn 1602-3: „Nú kemur hinn priðji vetur í harðindum; varð pá mannfall mikið af fátæku fólki af sulti um allt Ísland.“ Jón Espólín, Íslands árbakur i söguformi, V. deild, Kaupmannahöfn: Hið íslenska bókmenntafélag, 1826, bls. 99. 
afurð, pá sýnir skírskotun myndarinnar til náttúruhamfara að hvalir héldu lengi stöðu sinni sem tákn illra fyrirboða, sem ýtti undir öðrun hvalsins innan samtímamenningar.

\section{Að teikna blutina nákvemlega}

„Náttúrufræði er ekkert annað en að nefna pað sýnilega“ skrifaði Michel Foucault í bók sinni Orðin og hlutirnir. ${ }^{69}$ Eftir pví sem skipulagðar hvalveiðar jukust og urðu að arðbærri atvinnugrein pá dró úr skrímslavæðingu hvalsins. Sænski náttúrufræðingurinn Carl Linnaeus (1707-1778) gaf plöntum, dýrum og steintegundum latínunöfn byggð á tvöföldu pekkingarkerfi sem hann próaði auk pess sem hann sannfærði náttúruvísindamenn um alla Evrópu um pekkingarfræðilegt gildi mynda og mikilvægi peirra við tegundaflokkun. ${ }^{70}$ Flokkunarkerfi hvala var hinsvegar lengi á reiki og par sem orðið fiskur var notað um flestar pekktar lífverur sjávar, pá voru hvalir taldir til fiska langt fram á átjándu öld.

Fyrstu tilraunir til að gefa heildstæða mynd af lífríki og menningu Íslands er að finna í Íslandslýsingum feðganna, Skálholtsbiskupanna, Odds Einarssonar (1559-1630) og Gísla Oddssonar (1593-1638). ${ }^{71}$ Hvölum er par lýst stuttlega og engar furðusögur sagðar af hvölum eða öðrum „fiskum“. Hvölum er hins vegar lýst nokkuð nákvæmlega í Íslandslýsingu Jóns Guðmundssonar lærða (1574-1658), Ein stutt undirrietting um Ílands aðskiljanlegar náttúrur, skrifuð frá 1640-1645..$^{72}$ Talið er að stór örk sem sýnir teikningar af nítján nafngreindum hvalategundum og einum rostungi sé höfundarverk Jóns. ${ }^{73}$ Myndirnar eru dregnar upp með skýrum útlínuteikningum, pannig að dýrin eru sýnd flöt á hlið svo hægt sé á einfaldan hátt að bera kennsl á hinar ólíku tegundir út frá líkamseinkennum peirra, munnsvip, og áferð

${ }^{69}$ Michel Foucault, Les mots et les choses, Paris: Edition Gallimard, 1966, bls. 144.

70 Isabelle Charmantier, "Carl Linnaeus and the Visual Representation of Nature“, Historical Studies in the Natural Sciences, 41: 4/2011, bls. 365-404; Renzo Baldasso, „The Role of Visual Representation in the Scientific Revolution. A Historiographic Inquiry“, Centaurus 48: 2/2006, bls. 69-88.

71 Oddur Einarsson, Íslandslýsing. Qualiscunque descriptio Islandiae, Reykjavík: Bókaútgáfa Menningarsjóðs, 1971; Gísli Oddsson, Annalium in Islandia farrago and De mirabilibus Islandiae, ritstj. Halldór Hermannsson, Ithaca, NY: Cornell University Library, 1917.

72 Viðar Hreinsson, fón lerði og náttúrur náttúrunnar, bls. 578-584.

73 Myndblað GKS 1639kvart er varðveitt í Konunglegu bókhlöðunni í Kaupmannahöfn. Sótt 5. september 2019 af https://nmsi.is/wp-content/uploads/2016/11/ Hvalamynd-JPEG.jpg. Myndblaðið er birt í Viðar Hreinsson, fón lerði og náttúrur náttúrunnar, bls. 444-445. 
húðarinnar. Hvalirnir eru flestir af raunverulegum, náttúrufræðilegum toga. Jón dregur upp skýr tegundaeinkenni, sýnir til að mynda hnúðana á baki sandlægjunnar og skegg og tær rostungsins sjást greinilega. ${ }^{74}$ Mynd Jóns af náhval er hins vegar teiknuð samkvæmt lýsingu í Konungs skuggsjá sem hljómar á pann veg

En hann hefir tennur í höfði og allar smáar fyrir utan eina tönn mikla, og stendur sú í efra gómi í öndverðu höfði hans. Hún er fögur og vel vaxin og svo rétt sem laukur. Hún er 7 álna löng, sú er lengst kann að verða, og snúin öll svo sem hún sé með tólum gjör. Hún stendur rétt fram úr höfði honum, pá er hann fer leiðar sinnar. En svo hvöss, sem hún er, og rétt, pá verður honum engin vörn að henni, heldur er hann svo virkur að henni og kær, að hann lætur par ekki vætta við koma. ${ }^{75}$

Hvalateikningar Jóns lærða bera vott um svo mikla pekkingu á hvölum að ljóst er að hann hefur séð dýrin eða fengið mjög nákvæmar lýsingar af peim. Pá lýsir hann einnig nákvæmlega afurðum hvalsins: lýsi, spiki og tönnum, enda pekkti hann vel til hvalveiða og skrifaði pví út frá reynslunni. En prátt fyrir að myndir hans séu gerðar af nákvæmni, pá sýnir myndgerðin ákveðna seinkun, séu pær bornar saman við niðurlensku prentmyndirnar sem hér hefur verið lýst. Teikningar hans og frásagnir eru blanda bóklegrar pekkingar og eigin reynslu. Pær eru „afurð tvennra tíma eins og kort Ortelíusar." Jafnframt minna pær á hvalamyndir Gessners og kveikja pví spurningar um fyrirmyndir Jóns. Notkun myndanna er ekki ljós og rannsókn á peim bíður pví betri tíma.

Á Íslandi var lengi talað um hvalfiska og albýðufræðimaðurinn, Jón Ólafsson úr Grunnavík kallar seli hárfiska og hvali stórfiska í Fiskafreði sinni frá 1737. Jón birti „1́ heilu lagi fiskatalið og hvalatalið úr nafnapulum Snorra Eddu og tekur einnig orðrétt upp lýsingar á sjávardýrum úr Konungs skuggsjá. “77 Pá bjó hann til sitt eigið flokkunarkerfi eftir pví hvort yfirborð fiskanna væri hrjúft eða slétt viðkomu og ritaði kafla um illlhveli og ýmis konar skrímsli og blendinga eins og og marmennil, vatnahesta, sænaut og

74 Viðar Hreinsson, fón lerði og náttúrur náttúrunnar, myndin af sandlægjunni er á bls. $585 \mathrm{og}$ sú af rostungnum á bls. 591 .

75 Konungs skuggsjá, bls. 31.

76 Viðar Hreinsson, fón lerði og náttúrur náttúrunnar, bls. 580.

77 Póra Björk Hjartardóttir, „Inngangur“, Jón Ólafsson úr Grunnavík. Náttúrufreði. Fiskafreði - Steinafreði, ritstj. Guðrún Kvaran og Póra Björk Hjartardóttir, Reykjavík: Góðvinir Grunnavíkur Jóns, 2007, bls. 13-22, hér bls. 14. 
hafgýgar. Pannig lifði Jón með annan fótinn í frásagnar- og hugmyndakerfi sextándu aldar, pegar pví var enn trúað að á landi lifðu hin fullkomnu dýr, en eftirlíkingar peirra í sjó. ${ }^{78}$

Engin pekking á flokkunarkerfi Linnaeus virðist hafa borist til Íslands og sjálfur dró Linnaeus lengi að gera grein fyrir tegundaflokkun hvala, jafnvel pótt slík vitneskja lægi fyrir, par á meðal hjá danska guð- og dýrafræðingnum Erich Pontopiddan (1698-1764), og í Færeyjalýsingu Lucas Jacobsøn Debes (1623-1675). Auk pess gerðu hvalveiðimenn sér grein fyrir líffræðilegri sérstöðu hvala. ${ }^{79}$ Pað var sænski náttúrufræðingurinn Peter Artedi (1705-1735), svokallaður faðir fiskafræðinnar, sem skar loks úr um að hvalurinn væri spendýr og aðgreindi par með hvali frá fiskum í riti sínu Bibliotheca et Philosophia Ichtbyologica sem kom út $1738 .^{80}$ Tuttugu árum síðar flokkaði Linnaeus tólf hvalategundir með spendýrum í tíundu útgáfu af Systema naturae (1758).

Eggert Ólafsson (1726-1768) og Bjarni Pálsson (1719-1779), síðar landlæknir, ferðuðust um Ísland með stuðningi konungs og Konunglega danska vísindafélagsins árin 1752-1757 og söfnuðu upplýsingum um náttúru landsins, pjóðlíf og atvinnuhætti. Í Ferðabókinni (d. Reise igiennem Island) sem Eggert samdi, og kom fyrst út á dönsku árið 1772, heldur Eggert pví fram í formála bókarinnar að

[á]n teikninga get[i] ókunnugur maður ekki svo greiðlega gert sér fulla grein fyrir hvernig íslenzk fjöll, heitir goshverir og tiltekin héröð líta út. Með ímyndunaraflinu einu er einnig erfitt að skapa sér skýra mynd af tilteknum steintegundum, (...) Dýrin eru flest sýnd í náttúrulegum stellingum, svo að ókunnugur maður, sem skoðar sig um í ríki náttúrunnar, á að geta pekkt pau aftur. ${ }^{81}$

78 Helgi Hallgrímsson, „Fiskafræði Jóns Ólafssonar í samtíma hans“, fón Ólafsson úr Grunnavík. Náttúrufreði. Fiskafreði - Steinafreði, ritstj. Guðrún Kvaran og Póra Björk Hjartardóttir, Reykjavík: Góðvinir Grunnavíkur Jóns, 2007, bls. 23-29, hér bls. 27.

79 Klaus Barthelmess og Ingvar Svanberg, "Linnaeus' Whale. A wash drawing of bottlenose whales (Hyperoodon ampullatus) at Hammarby, with remarks on other early depictions of the species“, Lychnos. Annual of the Swedish History of Science Society, 2006, bls. 303-317, hér bls. 305.

80 Peter Artedi (1705-1735), Bibliotheca Icbthyologica og Philosophia Icbthyologica, 1738. Sótt 5. janúar 2020 af https://www.biodiversitylibrary.org/bibliography/153568\#/ summary.

81 Eggert Ólafsson, Ferðabók Eggerts Ólafssonar og Bjarna Pálssonar um ferðir peirra á Íslandi árin 1752-1757, Reykjavík: Bókaútgáfan Örn og Örlygur, 1975, hér I. bindi, bls. XXVI- XXVII. 


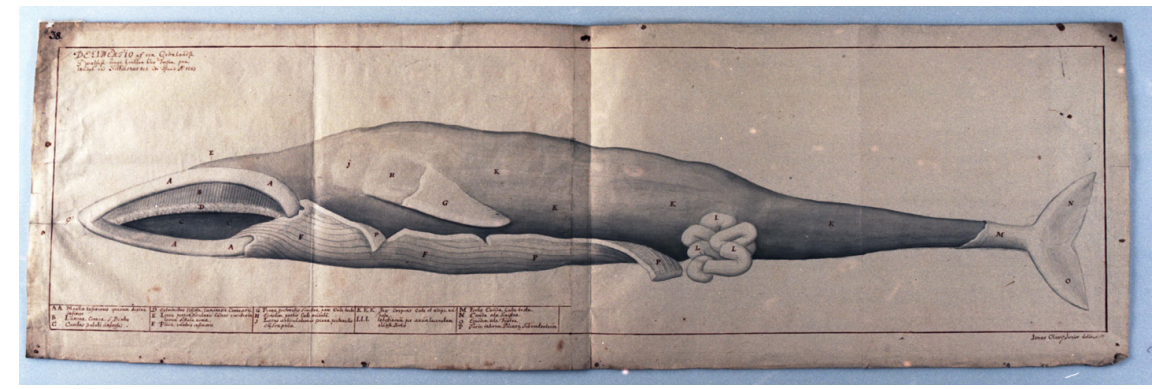

Jón Ólafsson yngri (1738-1775), Grenlandsbvalur, 1763. Pjóðminjasafn Íslands.

Hlutverk teikninga var að hans mati óumdeilanlegt og hann réði nokkra teiknara til starfsins til að skýra ýmis náttúrufyrirbæri, pjóðhætti og dýr. Varðveist hafa um 120 teikningar af fuglum, fiskum og steintegundum sem Eggert lét gera með útgáfuna í huga auk pess sem eirstungur voru gerðar eftir öðrum myndum og birtar í bókinni. Teiknararnir voru Ole Berg (17271763), Michael Fosie (1724-1794), og Hans Liunge (ópekktur), en eftir pann síðastnefnda liggja litríkar fugla- og fiskamyndir. ${ }^{82}$ Bróðir Eggerts, Jón Ólafsson yngri frá Svefneyjum (1738-1775), mun hafa lært teikningu pegar hann var í námi í Kaupmannahöfn. ${ }^{83}$ Nokkrar myndir í myndasafninu eru undirritaðar með hans hendi, par á meðal mjög nákvæmar myndir af steinum og ein mynd af hval. Hún sýnir Grænlandshvalinn, eða norðhvalinn, sem rak á fjörur við Seltjarnarnes árið 1763. Petta er ekki útlínumynd í ætt við teikningar Jóns lærða, heldur skýringarmynd, par sem teiknarinn aðgreinir og nefnir með latínuheiti líkamshluta hvalsins af vísindalegri nákvæmni. ${ }^{84}$ Hún sker sig pví frá öðrum teikningum í Ferðabókinni, sem sýna dýr í náttúrulegu umhverfi sínu án nokkurs skýringatexta. Myndin er afar fínleg og nákvæmlega dregin með penna og bleki. Líkami hvalsins er litaður með blágráu pvegnu bleki, og endurspeglar ljóst yfirbragð myndarinnar ef til vill hugmyndir manna um hreinleika hvalsins. Í Konungs skuggsjá er fæðu norðhvalsins lýst sem sérstaklega hreinni:

82 Egill Snorrason, „Eggert Olafsens's og Biarne Povelsen’s Rejser gennem Island 1749-1757 og illustrationerne dertil“, Arbók bins islenzka fornleifafélags, 1. janúar 1972, bls. 81-98, hér bls. 93.

83 Póra Kristjánsdóttir, Mynd á pili. Íslenskir myndlistarmenn á 16., 17., og 18. öld, Reykjavík: JPV útgáfa og Pjóðminjasafn Íslands, 2005, bls. 118-120.

84 Myndin er varðveitt í Pjóðminjasafni Íslands. Sótt 5. september 2019 af http:// sarpur.is/Adfang.aspx?AdfangID=692902\&Paging=false. 
En pessi fiskur lifir hreinlega, pví að pað segja menn, að hann hafi enga fæðslu aðra en myrkva og regn pað, sem fellur úr lofti ofan á haf. Og pó að hann sé veiddur og innyfli hans opnuð, pá finnst ekkert óklárt í hans maga sem annarra fiska peirra, er fæðslu hafa, pví hans magi er hreinn og tómur. ${ }^{85}$

Meltingarkerfi norðhvalsins vakti pví sérstakan áhuga manna og endurspeglast hann hugsanlega í teikningu Jóns. Myndin er merkt listamanninum neðst í hægra horni: „Jonas Olavius Junior delineavit,“ eða Jón Ólafsson yngri teiknaði.

Hvalrekinn á Seltjarnarnesi sætti talsverðum tíðindum, enda sjaldgæft að sjá norðhval á Íslandi. Rekans er getið stuttlega í Höskuldsstaðaannál: „Hval nokkurn rak syðra um sumarið.“86 Pá er stærð hvalsins lýst mjög nákvæmlega í Djáknaannál:

Hval rak á Seltjarnarnesi um sumarið 56 fóta langan, 41 fótar og 8 pumlunga pykkvan, kjálkinn var 13 fóta, skíðin 368, hvar af 41 voru stærst, vélindið 8 fóta langt og 7 pumlunga vítt parmarnir frá maganum með endagörninni 354 fet og víddin 12 pumlungar. Hryggjarliðarnir 63, peir 3 fremstu og 14 öftustu ekki holir. Augntóftin 10 pumlunga löng og 7 1⁄2 pumlungur á vídd. ${ }^{87}$

Ögn nákvæmari lýsing á hvalnum birtist í Ferðabók Eggerts og Bjarna. ${ }^{88}$ Teikning Jóns rímar vel við pessa skriflegu lýsingu sem hljómar eins og skýring við myndina, pví hún sýnir nákvæma staðsetningu líffæra hans. Bjarni Sæmundsson (1867-1940), náttúrufræðingur, telur að hvalurinn hafi „vel getað verið önnur hvor sléttbakstegundin. “89 Hann segir jafnframt: „tala hryggjarliða (863) og skíða (368) er of há fyrir báða sléttbakana, en svipuð og í steypireyði eða langreyði, svo erfitt er að vita, um hvaða hval hefir verið að ræða.“90

85 Konungs skuggsjá, bls 32.

86 Magnús Pétursson, „Höskuldsstaðaannáll 1730-1784“, Annálar 1400-1800, fjórða bindi, Reykjavík: Hið íslenzka bókmenntafélag, 1940-1948, bls. 463-603, hér bls. 515.

87 „Úr Djáknaannálum 1731-1774“, Annálar 1400-1800, sjötta bindi, Reykjavík: Hið íslenzka bókmenntafélag, 1987, bls. 1-330, hér bls. 128. Pá fjallar Bjarni Sæmundsson um hvalinn í Spendýrin, Reykjavík: Bókaverslun Sigfúsar Eymundssonar, 1932, bls. 412 og í Mammalia, Kaupmannahöfn: Munksgaard, 1939, bls. 33.

88 Ferðabók Eggerts Ólafssonar og Bjarna Pálssonar um ferðir peirra á Íslandi árin 17521757, hér II. bindi, bls. 228.

89 Bjarni Sæmundsson, Spendýrin, bls. 412.

90 Sama heimild. 
Teikning Jóns beinist að pví að greina tegundina á anatómískan hátt sem var nýlunda sé borið saman við aðrar myndir í bókinni. Pá var nýnæmi í íslensku samhengi að skrá fundarstað og fundartíma eins og Jón gerir í vinstra horni myndarinnar: „, Teikning af ungum grænlandshvalfiski sem rak á land við Seltjarnarnes út við Íslandi árið 1763“.91 Staðfesting á pví að teiknarinn hafi verið á staðnum styrkir augljóslega trúverðugleika myndarinnar pannig að hún er í senn vísindalegt rannsóknargagn og annáll um pað sem gerðist.

Jón yngri gerði aðra, en mjög ólíka teikningu af hámeri. Myndin er útlínuteikning en er afmörkuð á sama hátt og hin innan fínlegs ramma sem dreginn er með einu pennastriki. Myndin sýnir fiskinn á hreyfingu og með opin augun eins og hann væri lifandi. Nafn tegundarinnar er ritað efst í vinstra horni og teikningin er undirrituð: „Jón Ólafsson yngri gerði“, ${ }^{92}$ neðst í hægra horni. Dagsetningu vantar og ekki er vísað í neinn ákveðinn fundarstað, pannig að myndin er trúlega eftirgerð annarrar myndar.

Ein mynd af hákarli er í safninu. Hún er teiknuð af Hans Liunge árið 1757 og sýnir dýrið í hefðbundinni, kyrrstæðri fiskastellingu. Mælikvarði með pumlungamáli er teiknaður neðst á blaðið svo hægt sé að gera sér grein fyrir stærðarhlutföllum pess. Liunge virðist ekki hafa séð hvali, en hann gerði fjölda litríkra og lifandi mynda af fuglum, sem voru teiknaðar eftir fuglshömum eins og venja var. Hann sviðsetur fuglana í ímynduðu náttúrulegu umhverfi sínu á sama hátt og hann teiknar sel með kóp liggjandi á útskerjum. Pannig mætast ólíkar myndgerðir í útgáfuverki Eggerts og greinilegt að pær voru gerðar á mörkum tveggja tíma pegar ólíkar leiðir til framsetningar á dýrum og jurtum voru stundaðar. Annars vegar sú sem beindist að pví að sýna dýrin í náttúrulegu, trúverðugu umhverfi, hins vegar mun skýrslulegri framsetning, í anda flokkunar og vísindalegrar pekkingarsköpunar Linnaeusar, par sem líffæri og líkamshlutar eru aðgreindir og peim gefin latínunöfn.

\section{Nýlenduveiðar á norðurslóðum}

Hvalveiðar urðu að umfangsmikilli atvinnugrein stórveldanna og markmið peirra var fyrst og fremst að afla hráefna. Hvalurinn var einskonar olíulind, pví fyrir utan að vera fæðustofn til manneldis, pá voru hvalaafurðir nýttar

91 Tilvitnun hljóðar svo í frumtexta: „Delineatio af en Grönlandsk Hvalfisk-unge hvilken blev drefen paa landet ved Seltiarnarnes udi Island Anno 1763.“

92 „Jo Olavius junior fecit“. 
í ýmiss konar iðnað og framleiðslu, meðal annars á ljósmeti. ${ }^{93}$ Hollenskar sjávarmyndir frá sautjándu og átjándu öld endurspegla pennan veruleika og varpa ljósi á pessa próun. Tilgangur peirra var að sýna yfirburði Hollendinga í Norðurhöfum. Prenttækninni fleygði fram og átti pátt í að skapa sterka ævintýraímynd í kringum hvalveiðar á norðurslóðum í enskum, frönskum og pýskum blöðum og tímaritum á nítjándu öld. Par er áhersla á að draga upp ævintýralega mynd af hvalveiðum, sýna úfið hafið, skipin, vinnslustöðvarnar, stærð hvalanna og baráttu mannsins við dýrið og náttúruöflin. ${ }^{94}$

Ljósmyndarar tóku við skrásetningarhlutverki teiknara og málara á síðari hluta nítjándu aldar og ljósmyndir urðu öflugt áróðurstæki til að skapa ímyndir um nýlendusamfélög bæði á norður- og suðurhveli jarðar. Bandaríkjamaðurinn Thomas Roys (1815-1877) stundaði tilraunaveiðar við Ísland á árunum 1863-1872. Hann var frumkvöðull á sviði hvalveiða og setti upp vélvædda hvalstöð á Vestdalseyri í Seyðisfirði, eina pá fullkomnustu á heimsvísu. $^{95}$

Norðurslóðaímynd Íslands sem frumstæðrar nýlendu á hjara veraldar birtist víða í myndablöðum erlendis og á póstkortum. Viðureignin við hvalinn var ætíð mikið sjónarspil bæði í hafinu og á flensiplaninu par sem skurðarmennirnir gengu til verks. Íslenskir jafnt sem erlendir ljósmyndarar skráðu umsvifin sem byggðu á nýlenduskipulagi í kringum stórhvaladrápin.

Danski læknirinn Sophus Hallas kom til Íslands árið 1867 í hvalveiðileiðangri sem var gerður út af Det danske Fiskeriselskab. ${ }^{96}$ Hann skrifaði um reynslu sína og athuganir á Íslandi og lýsir í smáatriðum eltingaleik og dauðastríði hvals sem var króaður af, innilokaður af hafís, skammt frá Teigarhorni. Frásögnin birtist ásamt mynd í danska tímaritinu Illustreret Tidende árið $1867 .{ }^{97}$ Par segir:

Öðru hverju gaf skepnan frá sér djúp, titrandi andvörp og blóðið lagaði í svo miklu mæli að sjórinn litaðist ljósrauður [...] Nú fór

93 Trausti Einarsson rekur sögu hvalveiða í bók sinni, Hvalveiðar við Ísland 1600 - 1939, Reykjavík: Bókaútgáfa Menningarsjóðs, 1987.

94 Sjá t.d myndir af hvalveiðum og veiðistöð í greininni „Pictures of the Polar Regions“, í The Illustrated London News, 13. október 1849, bls 248 og 249. „Lpr. 3959“, Pjóðminjasafn Íslands.

95 Smári Geirsson, Stórbvalaveiðar við Ísland til 1915, bls. 52-67.

96 Sophus Hallas, „Optegnelser om nogle paa en Hvalfangst - Tog i Havet omkring Island iagttagne Hvaler", Videnskabelige Meddelelser fra den naturbistoriske Forening $i$ Kjöbenhavn 1867, Kaupmannahöfn, 1868, bls. 150-201.

97 Smári Geirsson, Stórbvalaveiðar við Ísland til 1915, bls. 75-77. 

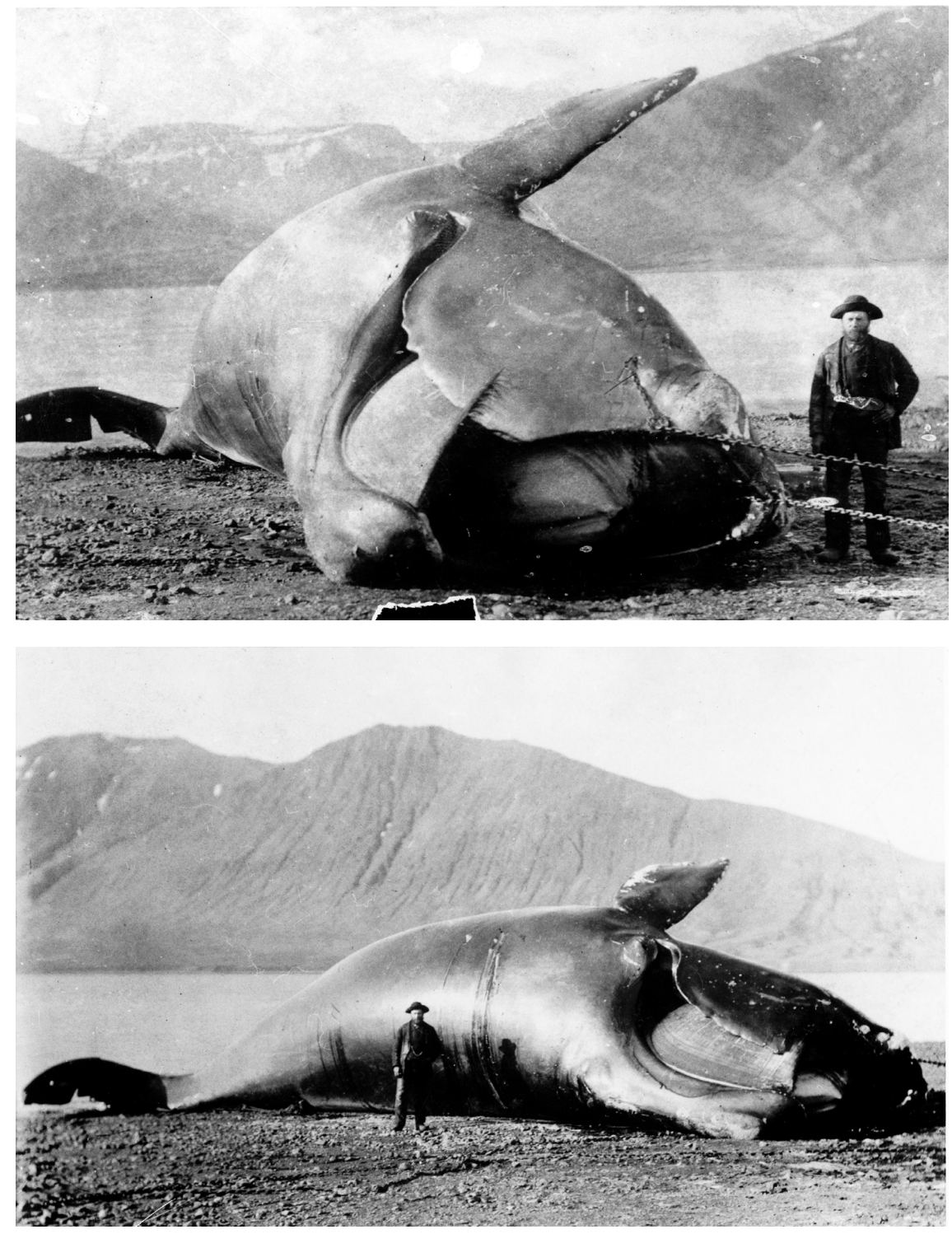

Hermann Wendel (1851-1922), Sléttbaksveiðar i Framnesi i Dýrafirði. Pjóðminjasafn Íslands.

annar hásetinn af bátnum upp á hvalinn, settist klofvega aftan við blástursopið, fór úr peysunni sinni og hóf að troða henni ásamt filthatti sínum niður í pað til að stöðva öndunina. ${ }^{98}$

98 Sama heimild, bls. 76-77. 
Hallas lýsir síðustu augnablikum hvalsins, hvernig hvalurinn „blés blóðlitum gufustrókum til lofts um leið og hann gaf frá sér djúpa hryglu sem reyndist vera sîðasta andvarpið.“99 Hann lýsir einnig spennunni meðal fólksins sem safnast hafði saman á ströndinni til að horfa á dauðastríð hvalsins og hvernig „prumandi fagnaðarhróp“ brustu á pegar hvalurinn gaf upp öndina. ${ }^{100}$

Fjallað er um hvalveiðar sem blómstrandi atvinnugrein í myndskreyttri grein í býska tímaritinu Das Buch für Alle (1883), en myndin sýnir fjölda dauðra stórhvela í flæðarmálinu og menn sem vinna á peim með skurðarjárnum. ${ }^{101}$ Ritið var, eins og nafnið gefur til kynna, einskonar fræðslu- og fjölskyldutímarit með myndum og ævintýralegum frásögnum frá hinum ýmsu heimshlutum.

Norðmenn reistu fjölda hvalveiðistöðva við Ísland á tímabilinu 18831915. ${ }^{102}$ Hvalstöðvarnar voru byggðar samkvæmt alpjóðlegri fyrirmynd. Peim fylgdu hvalveiðiskip, flutningaskip, vinnuafl og fjölpjóðlegt viðskiptanet sem var mun umfangsmeira en áđur pekktist á Íslandi. Ný porp uxu í kringum vinnsluna og atvinnutækin, plönin, bræðslurnar og verkafólkið mynduðu nýtt athafnarými, fyrst á Vestfjörðum, síðan á Austfjörðum, í leit að nýjum miðum. Settar voru á fót nýlendustöðvar, sem voru færðar úr einu landi yfir í annað eftir pví sem kapítalið bauð hverju sinni. Pannig voru til að mynda öll hús á Fögrueyri við Fáskrúðsfjörð tekin niður og endurreist á New Island á Falklandseyjum. Uppbygging hvalstöðvarinnar á Höfðaodda (Framnesi) hófst vorið 1890. ${ }^{103}$ Ljósmyndir sýna hvernig hvalirnir voru flensaðir í fjöruborðinu og peir liggja afspikaðir á ströndinni. ${ }^{104}$ Dauður Íslands-sléttbakur liggur í fjörunni í Dýrafirði, en hann var eitt af sjö dýrum af pessari sjaldgæfu tegund sem voru verkuð í firðinum árið $1891 .{ }^{105}$ Myndin er tekin eins og veiðimynd, pað er að segja maður stillir sér upp fyrir framan bráðina, sem er margfalt stærri en hann sjálfur. Hann er með hatt á höfði og gilda úrkeðju á brjóstinu en andlit hans er dapurt par sem pað ber við svartan, glansandi skrokk dýrsins.

Myndir frá flensiplaninu á Asknesi gefa góða innsýn inn í hvalstöðina aflaárið 1903. Gufuskipið Barden sigldi inn með tugi hvala í eftirdragi, en

\footnotetext{
99 Sama heimild, bls. 76-77.

100 Sama heimild, bls. 76-77.

${ }^{101}$ Myndin birtist í pýska tímaritinu Das Buch für Alle, 1883. Lpr/2011-62, Pjóðminjasafn Íslands.

${ }^{102}$ Smári Geirsson, Stórbvalaveiðar við Ísland til 1915, bls. 115-368.

${ }^{103}$ Sama heimild, bls. 196. Sjá mynd á bls. 194-195.

${ }^{104}$ Sama heimild, myndir bls. 198 og 202.

${ }_{105}$ Sama heimild, mynd bls. 144.
} 


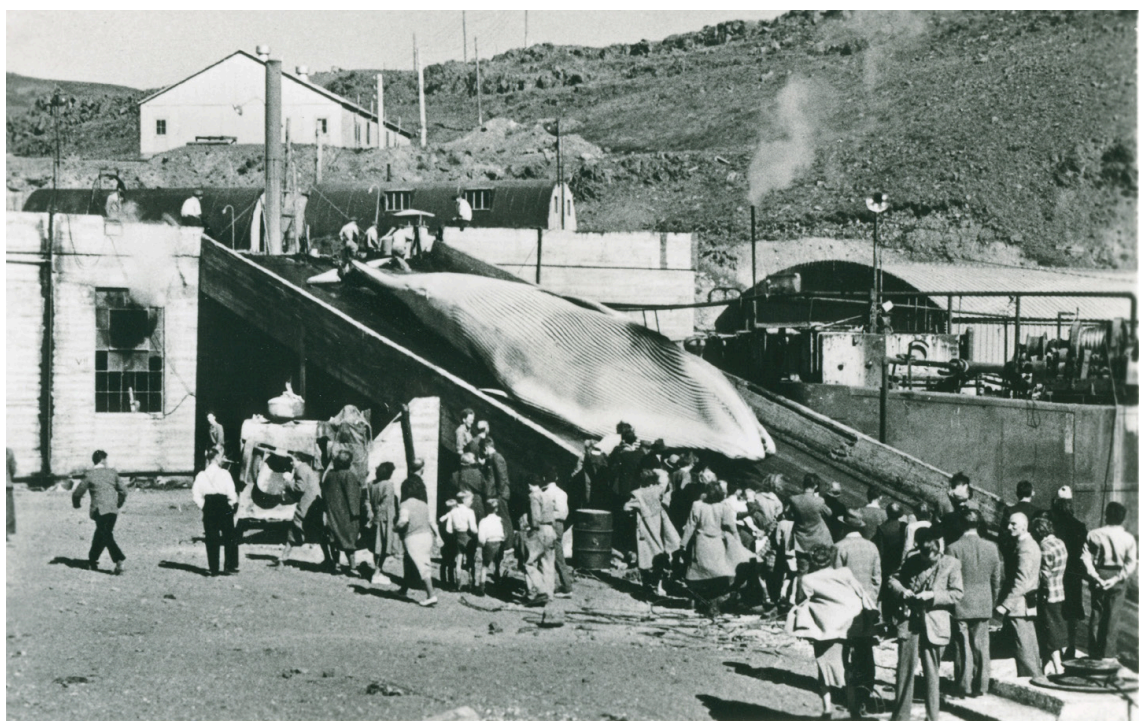

Thorvaldur R. Jónsson, Hvalstöðin i Hvalfirði, póstkort, 1952. Pjóðminjasafn Íslands.

jafnvel pótt stöðin væri sú stærsta og fullkomnasta í heiminum, pá höfðu menn í landi ekki undan að vinna hvalina. Alls 486 hvalir voru veiddir pá um sumarið og ljósmyndir sýna hvernig skíði, bein, kjöt og innyfli söfnuðust fyrir í hrúgum á planinu á ólíku stigi rotnunar og fnyks. ${ }^{106}$ Áhersla var lögð á spikið og annað feitmeti en skrokkarnir úldnuðu í flæðarmálinu pangað til tími gafst til að draga pá út á sjó og sökkva peim í sæ. ${ }^{107}$

\section{Sjónarspilið á bvalskurðarplaninu}

Árið 1935 hófst hvalveiðitímabil Íslendinga sem stóð fram til ársins 1986, pegar hvalveiðibann Alpjóða hvalveiðiráðsins tók gildi og íslenskir ráðamenn svöruðu með leyfi til vísindaveiða. ${ }^{108}$ Vinnslustöðin í Hvalfirði, Hvalur hf, sem hóf starfsemi árið 1948 var byggð á rústum flotastöðvar sem Bandamenn reistu í síðari heimsstyrjöld pegar Hvalfjörðurinn fylltist af skipum og olíutönkum. Í Hvalfirði var einnig rekin olíubirgðastöð (1951-1991) á vegum varnarliðsins og síðar Nató. Hvalstöðin varð vinsæll áningarstaður Íslendinga og erlendra ferðamanna sem gerðu sér ferð pangað til pess að upplifa blóðugan hvalskurðinn sem var umkringdur minjum um herstöðina.

${ }^{106}$ Sama heimild, bls. 283-284.

${ }^{107}$ Sama heimild, mynd bls. 285.

108 Karen Oslund, „The Image of Iceland in the Local and Global Nexus of Whaling Politics“, Iceland and Images of the North, bls. 285-303. 


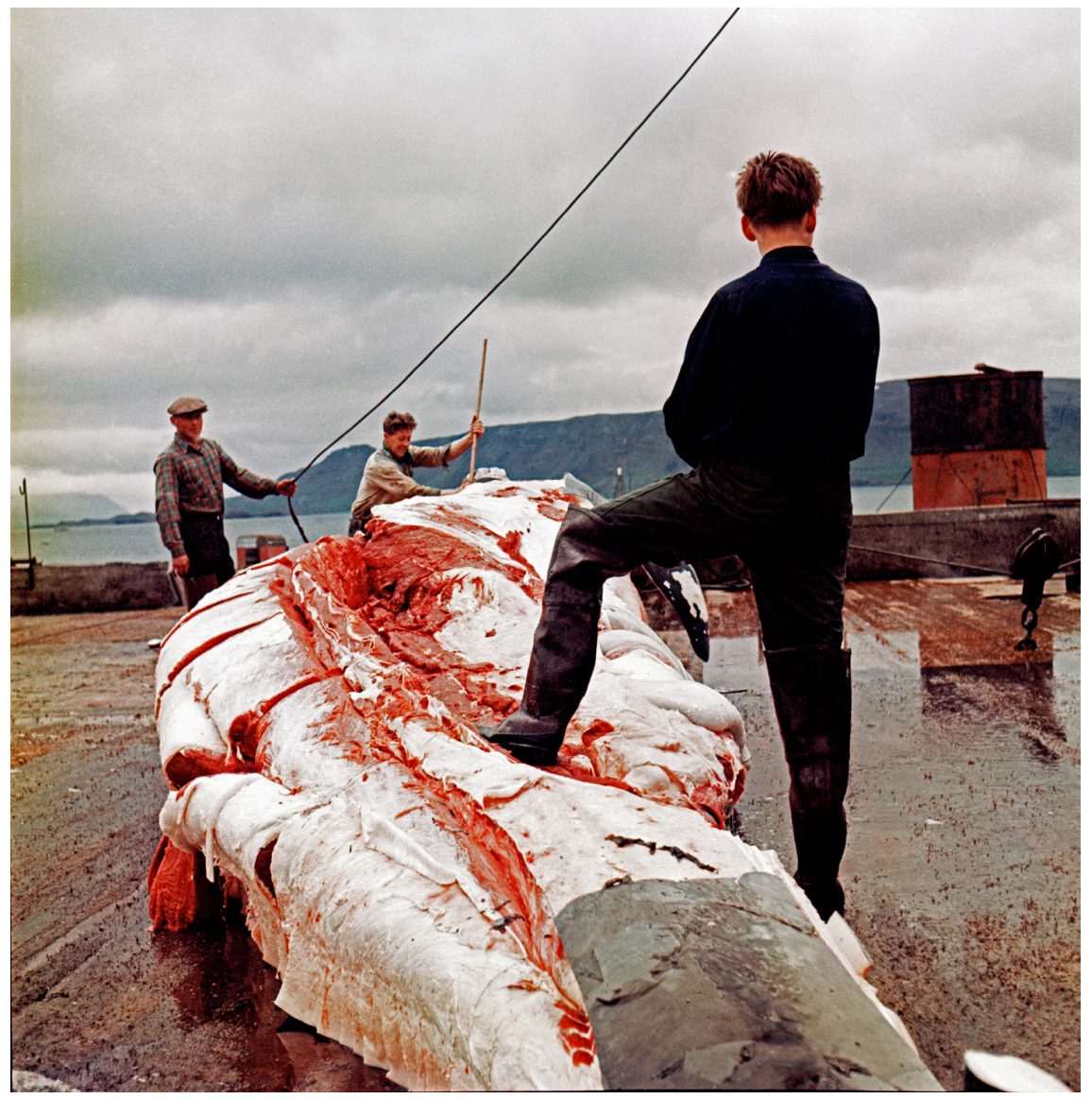

Helga Fietz (1907-1958), Hvalstöðin í Hvalfirði, 1954. Ljósmyndasafn Reykjavíkur.

Hvalveiðarnar urðu tákn íslenskrar atvinnumenningar og fjöldi ljósmynda frá síðari hluta tuttugustu aldar bregður ljósi á petta myndefni. Ferðaskrifstofa Íslands gaf út póstkort með ljósmyndum sem sýndu hvalskurð í Hvalfirði ${ }^{109}$ og myndir úr hvalstöðinni birtust í erlendum blöðum og í mörgum Íslandsmyndabókum, t.d. í vinsælli býskri ljósmyndabók Island. Insel aus Feuer und Eis. ${ }^{110}$ Á ljósmyndunum er athygli yfirleitt beint að karlmennsku hvalskurðarmannanna sem sundurlima líkama dýranna á blóði drifnu plani stöðvarinnar. Peir eru oft léttklæddir og prúðbúnir áhorfendur hópast að

109 Thorvaldur R. Jónsson, Hvalstöðin i Hvalfirði, Póstkort frá 1952, PK/1996-30, Pjóðminjasafn Íslands.

${ }^{110}$ Helga Fietz o. fl., Island. Insel aus Feuer und Eis, München: Hanns Reich-Verlag, 1955. Myndir hennar frá Íslandi eru varðveittar í Ljósmyndasafni Reykjavíkur. 


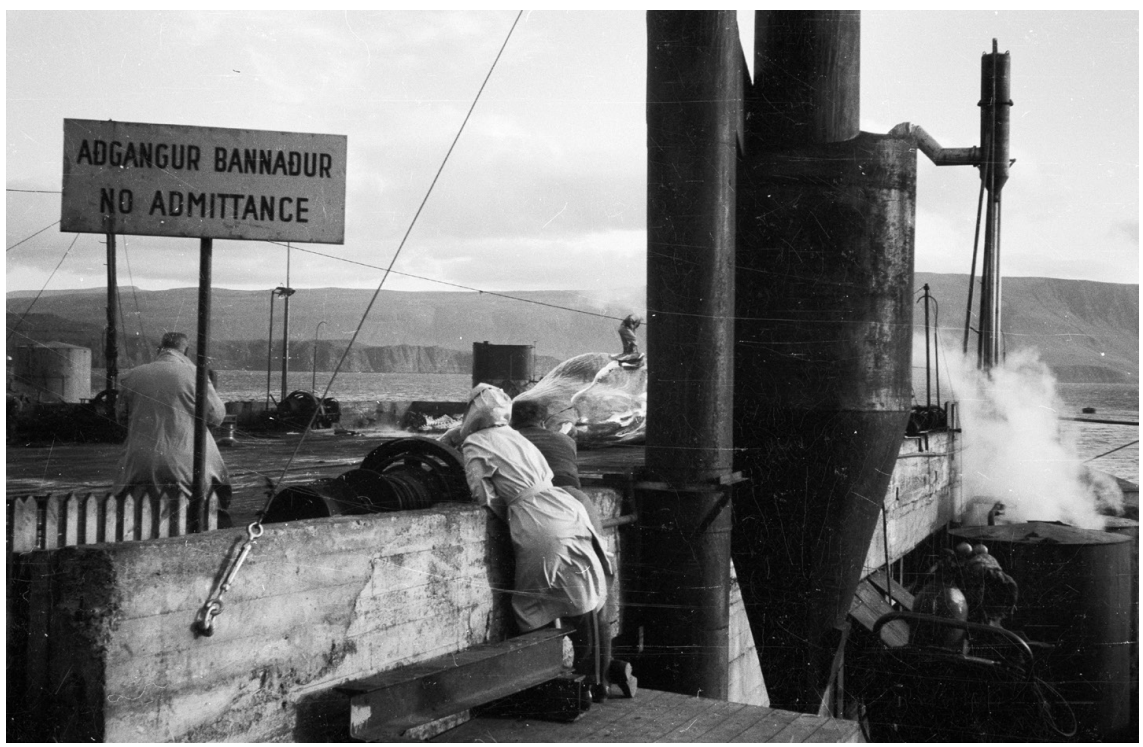

Pétur Thomsen eldri (1910-1988), Hvalstöðin i Hvalfirði. Ljósmyndasafn Reykjavíkur.

og njóta sjónarspilsins. Stundum sýna ljósmyndararnir hvalskurðarplanið í innilegu ljósi, eins og Pétur Thomsen eldri (1910-1988), sem skapar sterka tilfinningu fyrir innra og ytra rými, einmanaleika og bið í mynd par sem kona og maður deila planinu með dauðu dýrinu í heitri gufu ketilsins.

Fagurfræðilegt sjónarspil tortímingarinnar einkennir ljósmyndirnar sem hér hafa verið ræddar. Myndirnar frá Hvalstöðinni í Hvalfirði eru sjónminningarlegt safn um ágang Kalda stríðsins á hvalastofninn. Menning og náttúra renna saman í einn blóðugan farveg, par sem kjöt, bein og fita mynda einhverskonar rotmassa sem gekk af skurðinum. Myndirnar afbyggja sigursæla heimsmynd iðnvæðingarinnar. Pær mætti túlka sem sýnishorn af manngerðu trámatísku landslagi, pær ýfa upp sár sem breytir sýn okkar á framtíðina.

Vistvitund og umræða um náttúruvernd tók að hafa áhrif á almenning á Íslandi um 1970. Pá var fyrst deilt um virkjanaframkvæmdir og starfsemi álverksmiðjunnar í Straumsvík. Stjórnmálamönnum varð ljóst að pessar umræður væru ekki stundarfyrirbæri, eins og orð Hjörleifs Guttormssonar eru til vitnis um, en hann sagði: „Hér eru á ferðinni mál, sem munu ekki síður reyna á polrif mannkynsins í náinni framtíð en baráttan fyrir félagslegum umbótum. "111

${ }^{111}$ Hjörleifur Guttormsson, Vistkreppa eða náttúruvernd, Reykjavík: Mál og menning, 1974, bls. 7 . 


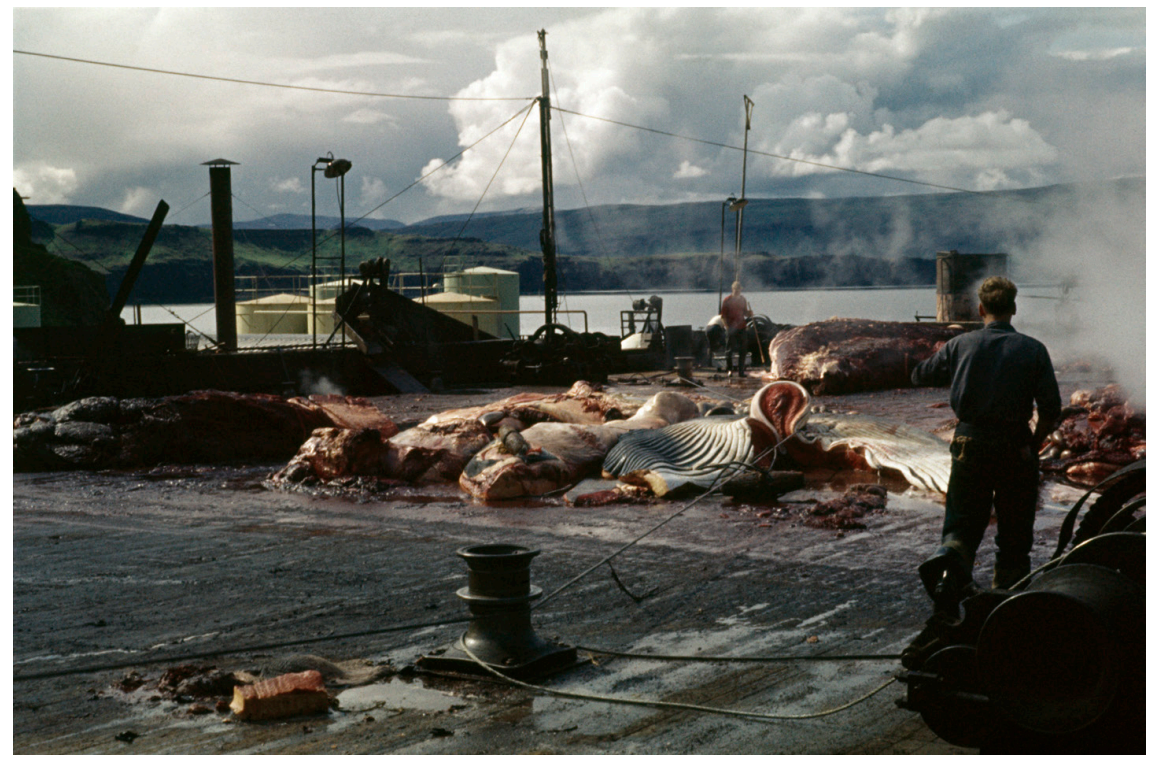

Gunnar Rúnar Ólafsson (1917-1965), Hvalstöðin í Hvalfirði. Ljósmyndasafn Reykjavíkur.

Breski Magnum ljósmyndarinn, Peter Marlow (1952-2016), kom til Íslands að undirlagi Greenpeace sumarið 1979 til að mynda drekkhlaðin hvalveiðiskip og verkamenn að störfum í stöðinni í Hvalfirði. Samtökin höfðu í hyggju að birta myndirnar í áróðursskyni, og líklega hefur pað verið í fyrsta sinn sem myndir af hvalskurði væru birtar í umhverfispólitísku samhengi. Jafnvel pótt myndir Marlows væru ekki svo ýkja frábrugðnar öðrum ljósmyndum sem teknar voru af frétta- og ferðamönnum í hvalstöðinni, umbreyttist merking myndanna í pessu nýja samhengi. Í stað pess að vera vitnisburður og minning um kitlandi sjónarspil urðu myndir hans sönnunargagn um aðferðir og atlögu manna við hvalveiðarnar. ${ }^{12}$ Árið 1986 bannaði Alpjóðahvalveiðiráðið allar hvalveiðar í atvinnuskyni. Alpingi sampykkti að hlíta pví banni. Sama ár voru skemmdarverk unnin á eignum Hvals hf og Paul Watson stofnandi Sea Shepherd Conservation Society reyndi að sökkva hvalbátum fyrirtækisins.

Aðgangi almennings að hvalskurðarplaninu var lokað og upplifun og áhorf ferðamanna færðist yfir á lifandi birtingarform dýrsins í sjónum. Hvalaskoðun hófst með skipulögðum hætti á Íslandi árið 1995 og hvalurinn varð, á nýjan hátt, hluti af ævintýraheimi norðursins sem síðan hefur verið

${ }^{112}$ Myndir Peters Marlows má skoða á vefsíðu Magnum Photos. Sótt 30. ágúst 2019 af https://pro.magnumphotos.com/Catalogue/Peter-Marlow/1979/ICELAND-Greenpeace-NN162170.html. 
auðkenndur sem ein helsta verslunarvara Íslendinga og uppspretta vistvænnar ferðamennsku á Norðurslóðum. ${ }^{113}$

\section{Sá stóri bvíti}

Listamenn settu fram smækkaðri og um leið tilfinningaríkari sýn á viðhorf náttúruverndarsinna til umhverfisins. Gylfi Gíslason (1940-2006) myndlistarmaður tákngerði eyðileggingu náttúrunnar í págu orkuframleiðslu í röð teikninga: Fjallasúrmjólk (1971) og Rafveðing (1977). Myndir hans deila á byggingu fyrstu stóru raforkuvirkjananna og álverksmiðjunnar í Straumsvík sem hóf framleiðslu árið 1969. Gagnrýni á afleiðingar olíuauðmagnsins á mannlíf og náttúru birtist einnig í ljós- og klippimyndum Valdísar Óskarsdóttur (f. 1949) í bókinni Rauði svifnökkvinn með texta Ólafs Hauks Símonarsonar. ${ }^{114}$

Náttúruvitund listamanna var miðlað í fjölda ljósmynda- og margmiðlunarverka um og eftir aldamótin 2000. Rúrí ljósmyndaði fimmtíu hverfandi fossa á Austurlandi til varðveislu í innsetningu sinni Archive - Endangered Waters á Feneyjatvíæringnum 2003. Hún gagnrýndi harðlega að virkjunarframkvæmdir á Íslandi væru knúðar áfram af óstöðvandi hagvaxtarsókn sem ógnaði jafnframt vatnsbúskap jarðar til framtíðar. ${ }^{115}$

Pétur Thomsen yngri (f. 1973) skráði umbreytingu ósnortinnar náttúru yfir í manngert landslag í págu orkuframleiðslu í ljósmyndasyrpunni Aðflutt landslag, en par sýndi hann jarðrask og byggingarframkvæmdir við Kárahnúkavirkjun frá 2003 allt pangað til peim lauk árið 2007. ${ }^{116}$ Ólöf Nordal (f. 1961) fjallar um ágang og græðgi Íslendinga gagnvart náttúrunni í útiverkinu Geirfugl sem var reist í flæðarmálinu rétt fyrir sunnan Reykjavíkurflugvöll í tilefni strandlengjusýningar Myndhöggvarafélagsins í Reykjavík árið 1998. Verkið minnir á eftirsjá Íslendinga eftir útdauðum fugli sem peir sjálfir áttu pátt í að útrýma. En jafnvel pótt pað sé mynd geirfuglsins sem vegfarandi kemur fyrst auga á í fjöruborðinu, pá er pað hvorki afsteypan né fuglinn sem slíkur sem er í forgrunni, heldur táknsagan á bak við verkið sem skiptir máli. ${ }^{117}$

${ }^{113}$ Arne Kalland, Unveiling the Whale Discourses on Whales and Whaling, Oxford: Berghahn Books, 2009.

114 Ólafur Haukur Símonarson og Valdís Óskarsdóttir, Rauði svifnökkvinn, Reykjavík: Heimskringla, 1975.

115 Verkin má sjá á heimasíðu listamannsins: ruri.is.

116 Esa Sigurjónsdóttir, Aðflutt landslag. Ljósmyndir Péturs Thomsen, ritstjóri Inga Lára Baldvinsdóttir, Reykjavík: Pjóðminjasafn Íslands, 2005.

${ }^{117}$ Auður A. Ólafsdóttir, „Nútímaafsteypur táknmynda. Um myndlist Ólafar Nordal“, 


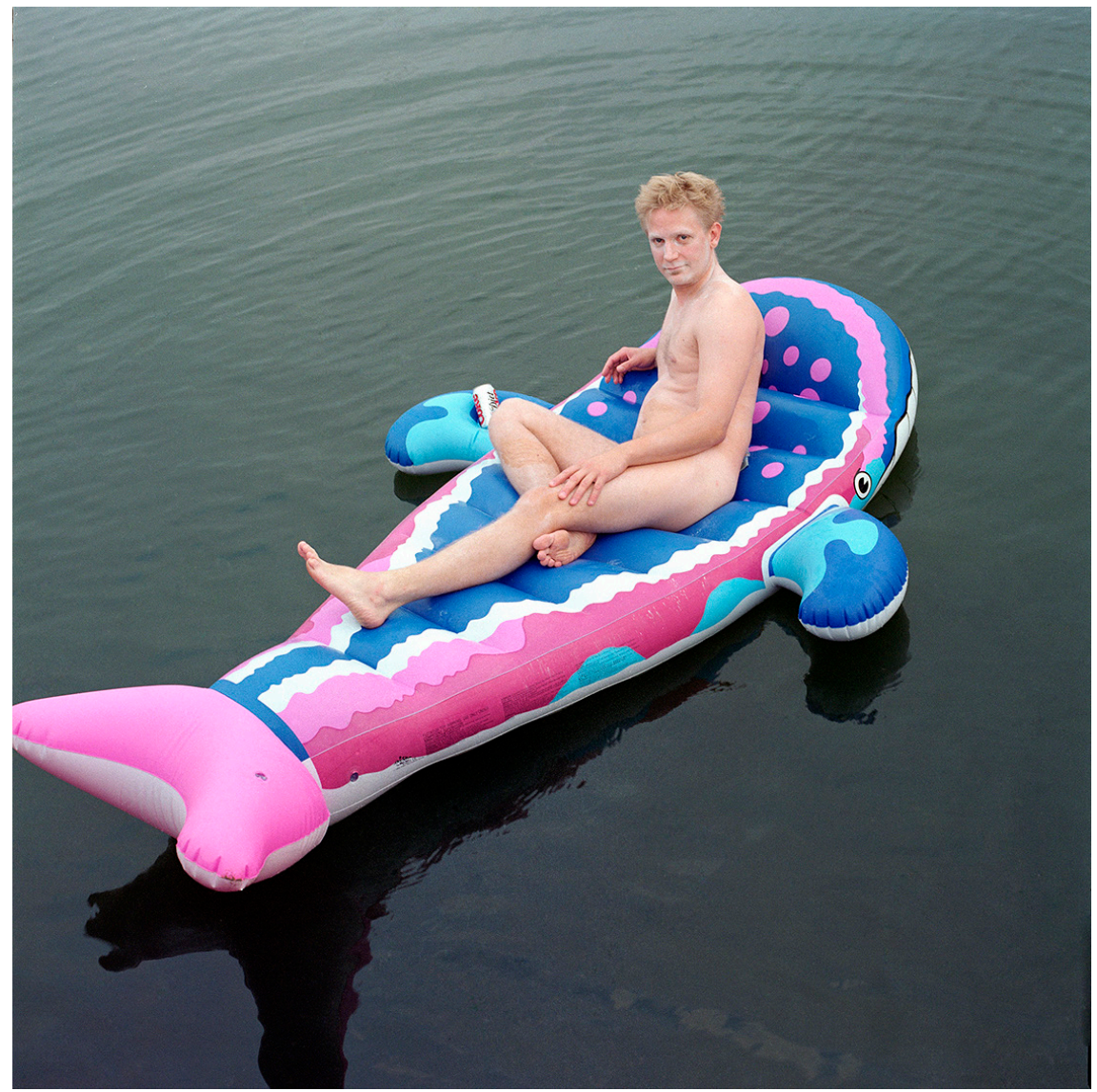

Magnús Sigurðarson, Sá stóri bviti (The Great White One), 1997. C-prent, 152x152cm. Ljósmynd: Jennifer Karady. Í einkaeigu.

Afsteypan úr gljáandi áli, er pví einskonar „spegill fortíðar,“118 - yfirborð hans skuggsjá, siðferðileg áminning og pólitísk ádeila á stóriðju og græðgi manna sem varð til pess að fuglinum var útrýmt. Verkið er kaldhæðin allegóría og sjálfan efniviðinn, álið, mætti jafnframt lesa sem vísun til pess að með stóriðju- og virkjanastefnunni sé græðgin gagnvart náttúrunni enn að verki.

Í verkum peirra Rúríar, Péturs Thomsens og Ólafar Nordal má greina

Skirnir, 2/2003, bls. 515-525, hér bls. 515-517. Katla Kjartansdóttir fjallar um útrýmingar- og varðveislusögu geirfuglsins í grein sinni, „The changing symbolic meaning of the extinct great auk and its afterlife as a museum object at the Natural History Museum of Denmark", Nordisk Museologi, 26: 2/2019, bls. 41-56.

118 Æsa Sigurjónsdóttir, „Aðdráttarafl upprunans“, Ólöf Nordal. Úngl, Reykjavík: Listasafn Reykjavíkur, 2019, bls. 135-163, hér bls. 155. 
blendnar tilfinningar, eftirsjá og samviskubit mannsins vegna peirra óafturkræfu áhrifa sem lífsmáti hans hefur haft á umhverfið. Myndlistamaðurinn Magnús Sigurðarson beitir hins vegar óbeisluðu háði í sviðsettum ljósmyndum og gjörningum par sem hann bendir á hvernig mannstýrðu lífshlaupi karlkyns háhyrningsins Keikós var umbreytt í söluvöru og útflatt merkingarlaust pjóðartákn. Keikó (sem áður hét Siggi eða Kago) var fangaður 1979 og komið fyrir í Sædýrasafninu í Hafnarfirði. ${ }^{119}$ Keikó var síðan seldur til til skemmtigarðsins Marineland í Ontario í Kanada og par var hann pjálfaður sem skemmtikraftur og leiðir hans lágu til Hollywood, par sem hann „sló í gegn“ í hlutverki sínu sem háhyrningurinn Willy í kvikmyndunum Free Willy. ${ }^{120}$ Eftir að hafa búið við slæman aðbúnað í sædýrasafni í Mexíkó var hann fluttur í sædýrasafn í Newport, Oregon í Bandaríkjunum par sem hann skemmti gestum. Háhyrningurinn var loks fluttur aftur til Íslands í september 1998 með flutningavél Bandaríkjahers til Vestmannaeyja. Tilgangurinn var að sleppa honum lausum í hafið par sem hann hafði verið veiddur tveimur áratugum áður. Hann var pjálfaður til að gera honum fært að lifa aftur upp á eigin spýtur. Er Keikó var svo sleppt árið 2002 synti hann til Noregs. Pann tólfta desember 2003 greindu fjölmiðlar frá dauða hans við Noregsstrendur. ${ }^{121}$

Árið 1997 ferðaðist Magnús pvert yfir Bandaríkin til pess að hitta „landa“ sinn í sædýrasafninu í Oregon, en ferðin var tilraun til pess að efla tengsl pessara tveggja spendýra og greina tilveru peirra í bandarísku neyslusamhengi. Í verkum sínum fæst Magnús iðulega við sjálfsmyndir og klisjur í formi ljósmynda og gjörninga. Á sýningunni Listamenn á barmi einbvers í Nýlistasafninu í júlí 1998, sýndi hann m.a. myndir úr ferðinni. Hann fór í hlutverk ferðalangsins vopnaður myndavél og kúrekastígvélum. Hann var kórdrengur að syngja íslensk ættjarðarlög og villimaður með alvæpni í Húsdýragarðinum. Í ljósmyndaverkinu Sá stóri bvíti (1997) ${ }^{122}$ situr hann

${ }^{119}$ Jón Már Halldórsson, „Hvað varð Keikó gamall?“, Vísindavefurinn, 31. október 2002. Sótt 2. nóvember 2019 af https://www.visindavefur.is/svar.php?id=2828.

${ }^{120}$ Free Willy myndirnar voru gerðar árin 1993, 1995, 1997.

${ }^{121}$ Um Keikó sjá: Anne Brydon, „Whale-siting. Spatiality in Icelandic nationalism“, Images of contemporary Iceland. Everyday lives and global contexts, ritstj. Gísli Pálsson og E. Paul Durrenberger, Iowa: University of Iowa Press, 1996, bls. 25-45; Anne Brydon, „Náttúran, mótmæli og nútíminn. Náttúrusýn Íslendinga - með augum gestsins“, Tímarit Máls og menningar 2/2001, bls. 45-49; Anne Brydon, „The predicament of nature. Keiko the whale and the cultural politics of whaling in Iceland", Anthropological Quarterly 79: 2/2006, bls. 225-260.

${ }^{122}$ Ljósmyndari Jennifer Karady. Myndin var fyrst sýnd á sýningunni Listamenn á barmi einbvers í Nýlistasafninu í júlí 1998. 
nakinn í kvenlegri hafmeyjarstellingu á uppblásinni plastdýnu sem er eins og hvalur í laginu. Blá augu listamannsins, rautt andlitið og hvít húðin kallast á við bleika, bláa og hvíta liti í plastbúk hvalsins sem flýtur á spegilsléttu vatni. ${ }^{123}$ Hér er öllu umsnúið. Hvítur karlmaður á sólarströnd í undirgefinni, kvenlegri tælandi stellingu á ljósmynd sem vísar í titli sínum til helsta vígis karlmennskunnar í bókmenntum, skáldsögunnar Moby Dick, eftir Herman Melville, sem fyrst kom út árið 1851. Sögupráður bókarinnar hverfist um eltingaleik hvalveiðimanna við pann stóra hvita og afhjúpar um leið iðnvæðingu veiðanna og tengsl hvalveiða við efnahagslegan uppgang Bandaríkjanna á nítjándu öld.

Verkið lýsir skipbroti hvíta karlmennskutáknsins sem listamaðurinn speglar í uppblásinni Disney-eftirlíkingu af Keikó. Myndin varpar jafnframt ljósi á hans eigin sjálfsmynd pegar hann uppgötvaði hvítleika sinn, p.e. pau forréttindi sem fylgja pví að vera „hvítur maður“ í Bandaríkjunum. ${ }^{124}$ Pannig felst í verkinu umsnúningur í takt við endurskoðun viðtekinna gilda, eins og pau birtust í gagnrýnum hvítleikafræðum í Bandaríkjunum í lok tuttugustu aldar. ${ }^{125}$ Magnús bendir á samslátt hvítunnar eða hvítleikans sem birtist í deilum um sérstöðu hvalveiða við Ísland við pá ímynd Íslendinga að vera boðberar hreinnar norrænnar veiðimenningar. ${ }^{126}$

Síðan hefur Magnús sett á svið Sálumessu bvals (e. Requiem for a Whale) sem var gjörningafyrirlestur um Keiko í sundlauginni í Kópavogi í október 2018, sem hluti af Cycle Festival Reykjavík. Verkið var framhald verksins Dansað með bvölunum (e. Dances with Whales (Keiko - Always on my Mind)), sem er götugjörningur, par sem uppblásnir háhyrningar og hvít froða líkja eftir sjónarspili ævintýramyndanna um Free Willy, og öðrum háhyrningasýningum í skemmtigörðum par sem dýrin leika listir sínar. ${ }^{127}$

${ }^{123}$ Eva Heisler, „Hugmyndir, hlutir og rými“, Ílensk listasaga frá sídari bluta 19. aldar til upphafs 21. aldar, ritstj. Ólafur Kvaran, V. bindi, Reykjavík: Forlagið og Listasafn Íslands, 2011, bls. 216-301, hér bls. 241.

${ }^{124}$ Tölvupóstur frá Magnúsi Sigurðarsyni til greinarhöfundar.

${ }^{125}$ Ruth Frankenberg, „Introduction. Local Whiteness. Localising Whiteness“, Displacing Whiteness. Essays in Social and Cultural Criticism, ritstj. Ruth Frankenberg, Durham: Duke University Press, 1997, bls. 1-34.

${ }^{126}$ Um hvítleika í íslensku menningarsamhengi: Kristín Loftsdóttir, „Negotiating White Icelandic Identity. Multiculturalism and Colonial Identity Formations“, Social Identities 17: 1/2011, bls 11-25.

127 Gjörningurinn var fyrst sýndur í MoMA PS1 í New York, og síðan endurgerður fyrir hóp dansara í samvinnu við danshöfundinn Danielle Georgiou. Gjörningurinn var einnig leikinn á vorviðburði listahátíðarinnar Cycle, Cryptopian States í Berlín 2018. Um sýninguna má lesa á kynningarsíðu KÍM, sótt 15. október af https:// icelandicartcenter.is/blog/cryptopian-states-berlin-germany/. 
Eins og Magnús bendir á í gjörningum og öðrum verkum hans sem fjalla á ólíkan hátt um lífshlaup Keikós, pá verður birtingarheimur hvalsins ekki aðskilinn frá valdbeitingu mannsins á dýrinu og speglar valdbeitingu Vesturlanda og auðmagnsins almennt á nýlendunum og afurðum peirra. Í gjörningunum tengir hann líf Keikos við nýlendustöðu Íslands og heldur pví fram að Ísland sé nyrsta karabíska eyjan, pví Ísland, ásamt karabísku eyjunum St. Croix, St. John og St. Thomas, voru allar nýlendur konungsríkisins Danmerkur. Gagnrýni hans beinist að pví að sýna hvernig nýlendurnar láti blekkjast af bandarískri neyslumenningu sem hlutgeri og umbreyti peirra eigin náttúru og dýralífi í blæti sem hafi glatað allri tengingu við upprunaleika og lífríki.

Með pví að velja uppblásinn Keikó sem pjóðartákn, varpar Magnús fram spéspegli svipuðum peim sem Ólöf Nordal sýndi Íslendingum í álafsteypunni af geirfuglinum. Um leið hæðist hann að hinu menningarlega sjónarspili sem er stýrt af vestrænni neyslumenningu og gagnrýnir hvernig hún hefur náð yfirhönd á Íslandi, par sem sambandi manna og dýra er miðlað með ímyndaklisjum og Disney-væðingu náttúrunnar. ${ }^{128}$ Nærtækt er að minna á blætisvæðingu dýrsins á Íslandi sem tekur á sig pjóðlega táknmynd ýmist í hvalaskoðunarferðum eða túristavarningi sem seldur er í svokölluðum lundabúðum. ${ }^{129}$

\section{Hvalreki á brotinni plánetu}

Раð er um áratugur síðan menn byrjuðu að reyna að bjarga strönduðum hvölum á Íslandi. ${ }^{130}$ Ljósmyndir af hvalreka sem birtust í fjölmiðlum sumarið 2019 bera vott um áhrif umhverfissiðfræði á viðhorf almennings til hvala.

Mynd Stefáns Karlssonar á forsíðu Fréttablaðsins 27. ágúst 2019 varpar ljósi á samúð manna gagnvart dýri sem er í hættu vegna ágangs mannsins. Maðurinn reynir að stjórna aðstæðum prátt fyrir að hafa misst stjórn á umhverfi sínu. Björgunarsveitarmenn bregðast við aðstæðum á meðan vísindamenn standa ráðalausir gagnvart atburðunum. ${ }^{131}$

${ }^{128}$ Disney-væðing samfélaga er rædd í menningarlegu, félagslegu og efnahagslegu samhengi í bók Alan Bryman, The Disneyization of Society, London: Sage Publications, 2004.

129 Blætisvæðing ferðamannaiðnaðarins á Íslandi er rædd í grein peirra Kötlu Kjartansdóttur, Katrínar Önnu Lund og Kristínar Loftsdóttur, „„PPuffin love“. Performing and creating Arctic landscapes in Iceland through souvenirs“, Tourist Studies, 18:2, 2018, bls. 142-158.

${ }^{130}$ Upplýsingar frá Ævari Petersen dýrafræðingi.

${ }^{131}$ Ingunn Lára Kristjánsdóttir, „Engin regla um hvalreka. „Hluti var urðaður og hluti 
Myndin er pví vitnisburður um að hugmyndafræði umönnunarlýðræðisins (e. care- democracy) hefur skotið rótum í fjölmiðlum meginstraumanna og að hvalurinn hefur ef til vill öðlast einhverskonar jafningjastöðu við manninn, sem sýnir meiri nærgætni gagnvart náttúrunni en áður. Tegund hvalanna skiptir ekki lengur höfuðmáli, né upplýsingar um stærð peirra, útlit, eða innræti. Björgunarsveitir eru nú kallaðar á vettvang til að bjarga dýrunum og starf peirra verður myndhverfing um hamfaraótta. Pannig hefur merking orðsins hvalreki umhverfst. Рað merkir ekki lengur happafengur heldur vekur upp samúð, hryggð og jafnvel tilfinningu fyrir missi. ${ }^{132}$ En prátt fyrir pessa viðhorfsbreytingu er hvalreki enn sjónarspil, jafnvel pegar hann birtist í vanmáttugum líkama skepnu sem parfnast umönnunar.

\section{ÚT DRÁTTUR}

\section{Sjónarspil tegundanna: Hvalurinn í öllum sínum (líf) myndum}

Myndir af hvölum hafa lítt verið rannsakaðar jafnvel pótt pær séu mikilvægar heimildir um pekkingu á tegundunum og próun iðnvæðingar í hvalveiðum. Pessi grein er pverfræðileg tilraun til að kanna hvernig hvalir eru - og hafa verið myndgerðir og hvernig listamenn gagnrýna ímyndir ráđandi sjónmenningar. Sýnt er fram á hvernig lífvaldið hefur mótað myndir og hvernig upplýsingatæknisamfélagið umbreytir myndgerð samtímans. Að lokum verður skoðað hvernig ný sýn á umhverfismál hefur skapað forsendur til að túlka myndir út frá sjónarhorni umhyggjusiðfræði.

Lykilorð: hvalir, hvalaskoðun, hvalreki, Keikó, ljósmyndun, mannöld, sjónmenning, samtímalist, umhverfisfræði, umhyggjusiðfræði

étinn““, sótt 14. janúar 2020 af https://www.frettabladid.is/frettir/engin-regla-umhvalreki-hluti-var-urdadur-og-hluti-etinn/.

${ }^{132}$ Giovanni Bearzi, Nino Pierantonio og Massimo Demma, „Perception of a cetacean mass stranding in Italy. The emergence of compassion", Aquatic Conservation. Marine and Freshwater Ecosystems, 20: 6/2010, bls. 644-654. Sótt 5. september 2019 af https://www.researchgate.net/publication/215875000_Perception_of_a_cetacean_ mass_stranding_in_Italy_The_emergence_of_compassion. 


\section{A B S T R A C T}

\section{From Species to Spectacle: The Whale in it's (bio) images}

Art historical and photographic representations of whales are an understudied category of images, even though they are considered to be an important evidence that informs knowledge about species and the development of industrialization in the whaling industry. This paper is an interdisciplinary attempt to investigate how whales have been - and are visually represented, and how artists rhetorically present critical alternatives to dominant visual culture. It is discussed how biopower has shaped the image of whales and how the information society constructs visual representations. Finally it will be demonstrated how the environmental turn has created new premises for interpreting images from the ethical perspective of care democracy.

Keywords: anthropocene, ethic of care, contemporary art, environmental studies, Keiko, photography, visual culture, whales, whale beaching, whalewatching

\section{Æsa SigurjónsdótTir}

Dósent í listfræði

Íslensku- og menningardeild

Hugvísindasviði Háskóla Íslands

Sæmundargötu 2

IS-102 Reykjavík, Ísland

aesas@hi.is 
